\title{
Does Downward Social Mobility Make People More Hostile Towards Immigrants?*
}

\author{
Marii Paskov, Patrick Präg, and Lindsay Richards
}

August 10, 2020

\begin{abstract}
This study explores the relationships between intergenerational social class mobility and attitudes towards immigration. We interpret a failure to keep up with parental social class (i.e. downward mobility) as an indicator that individual's status achievements lag behind expectations and contribute to subjective feelings of loss and decline. An innovative feature of this study is that we investigate both whether individual's mobility experience - micro-level - and also whether opportunity structuresmobility on a macro level - are linked with attitudes towards immigration. In contexts with high downward-mobility, opportunities for moving up are limited and hence perceived economic decline and loss might lead to more hostility towards immigrants. We use the European Social Survey data (2002-10) and conduct analyses on 30 countries using diagonal reference models that allow the effects of individual mobility trajectory to be disentangled from origin status and destination status. Our results show that the working classes hold stronger anti-immigration attitudes and parental class continues to exert an effect on attitudes in adulthood even after accounting for individual's own social class position. Being downwardly mobile from parental class does not appear to be associated with more hostility towards immigrants, except in a few European countries like Italy, Poland, and Greece. Our random-effects meta-regression models show, however, that people living in contexts of high downward mobility are more hostile towards immigrants compared to people in contexts with high upward mobility.

${ }^{*}$ This manuscript is forthcoming in Research in Social Stratification and Mobility. Previous versions of this manuscript were presented at the ASA annual meeting 2019 in New York and the RC 28 spring meeting 2019 in Frankfurt am Main.

Data analyzed in this study are publicly available (ESS, 2002, 2004, 2006, 2008, 2010). We provide a set of Stata do-files for replicating our analyses (Paskov et al., 2020).

Patrick Präg was supported by a grant (no. 681546, FAMSIZEMATTERS) from the European Research Council (ERC) under the European Union's Horizon 2020 research and inno-
\end{abstract} vation program. 


\section{Introduction}

Social and economic loss is a central theme in stratification and inequality research. A popular narrative that has emerged is the idea that social and economic loss could explain recent political trends, including the backlash against immigration. The argument is that in a context of stalling economic progress in otherwise rich countries, those who have lost out, or for whom status achievements lag behind expectations, are particularly discontented and attracted to anti-immigrant sentiment often endorsed by populist political parties (Gest, 2016; Gidron and Hall, 2017; Hochschild, 2016; Jackson and Grusky, 2018). The underlying assumption is that perceived or actual social and economic decline are contributing to feelings of competition, relative deprivation and frustration that are fertile grounds for hostile attitudes towards outgroups to flourish. This study explores this narrative by focusing the relationship between socioeconomic loss and attitudes towards immigration.

What exactly constitutes social and economic decline and how people interpret their socioeconomic losses and gains is still under-researched. In very simple terms, the assumption in much of the literature is that people dislike downward mobility - doing worse in social and economic terms as compared to some relevant benchmark. In sociological theory, and in stratification literature, in particular, intergenerational loss - doing worse than your parents - is seen to be of central importance. Families are assumed to have a strong incentive to try and reproduce their socioeconomic status and a failure to keep up with the social status of one's parents is interpreted as a form of social and economic loss or decline (Erikson and Goldthorpe, 1992). The underlying assumption is that 'children expect to do better - or at least to have a good chance at doing better - than their parents' (Chetty et al., 2017). The same motivation is shared by parents who want their children to do better or at least equally good as them but certainly not worse (Breen and Goldthorpe, 1997). What this then implies is that the experience of intergenerational downward mobility or the prospect of it should not leave families indifferent.

In this study, we investigate the narrative of loss by studying the relationship between intergenerational downward mobility and attitudes towards immigration. Intergenerational loss is a real concern in many modern societies where people are not any more doing better than their parents or they are even doing worse than their parents along various dimensions, including income and social class positions (Bukodi et al., 2020; Chetty et al., 2017). After a so-called 'golden era' of major occupational upgrading and shared economic growth in many advanced countries after the second world war, limited occupational upgrading together with rising income inequality have led to a situation where young people entering the labor market today face less favorable prospects than their parents did (Chetty et al., 2017; Bukodi et al., 2015, 2020; Grätz et al., 
2019). The question, then, is what are the broader implications of this 'mobility problem' that some countries are facing?

Declining economic conditions and opportunities are generally associated with rise in anti-foreigner sentiment (Semyonov et al., 2006). Scapegoat theory posits that this pattern is explained by the tendency for individual to blame outgroups when faced with adverse socioeconomic circumstances (Hammer, 2007; Semyonov et al., 2006). In a similar vein, Jackson and Grusky (2018) argue as part of their post-liberal theory of stratification that 'those experiencing loss will often blame others rather themselves.' While some might take one's losses as a personal defeat, many people are inclined to look for someone to blame or hold other people responsible for their losses. Immigrants then become an easy target of blame because they are seen as contributing to increased competition for jobs and other valuable resources. Importantly, however, scapegoat theory suggests that even if immigrants are not the true reason for the experience of economic decline, people can still channel their frustration towards outgroups as a form of psychological relief (Hammer, 2007; O'Flynn et al., 2014). What is more, some politicians are explicitly contributing to scapegoating and the rhetoric that immigrants, in particular, are to blame for socioeconomic decline and loss (Jackson and Grusky, 2018). This can then foster hostility towards immigrants among those who experience intergenerational loss or are at the risk of socioeconomic decline compared to their parents. However, this rhetoric can also contribute to hostility towards immigrants among people who have not directly experienced loss themselves, but also among those feeling solidarity with their 'native' in-group.

The innovative feature of our study is the fact that next to interpreting losses and gains in terms of one's own mobility experience (i.e. micro level mobility), we are to our knowledge the first to investigate the role played by mobility context - the rate of social mobility in the society as a whole (i.e. macro-level mobility). We thereby tackle the question set out by Lipset and Bendix (1959) who argued that an important question is whether the experience of social mobility or the mobility context one lives in make a difference for individual attitudes and behavior. First, regarding individual-level loss, we ask whether people who have experienced loss compared to their parents, the downwardly mobile, are more hostile towards immigration than people who have not experienced downward mobility. In the context of rising support for political parties that promote anti-immigrant sentiments, in Europe and beyond, there has been a growing emphasis on the 'left behind' and the 'cultural backlash' as driving forces behind attitudes and preferences (Engler and Weisstanner, 2020; Gidron and Hall, 2017; Norris and Inglehart, 2019). Thus, while some have claimed there is little evidence for economic theories of anti-immigrant attitudes (Ersanilli and Präg, 2020; Hainmueller and Hopkins, 2014), elsewhere there is rich 
evidence that certain groups in society (men, the working classes, the lesseducated) hold negative views towards outgroups due to perceptions of loss in terms of relative economic and social status (Gest, 2016; Gidron and Hall, 2017; Norris and Inglehart, 2019). Until now just a handful of studies have focussed on the experience of social mobility as an indicator of experienced loss, in order to explain attitudes towards immigration. This question was tackled before by Tolsma et al. (2009) but focusing on one country, the Netherlands. This study offered little evidence for the idea that the downward mobility experience leads to frustration and more hostility towards immigrants in the Dutch society. We provide updated evidence on the role of individual mobility experience for attitudes towards immigrants but for a sample of 30 European countries.

Second, regarding the mobility context, we ask whether people who live in contexts with high rates of downward mobility or unequal mobility chances are more hostile towards immigrants compared to people who live in contexts where downward mobility is less prevalent and where there is more equality of opportunity. Macro-level theories suggest that in a context of high downward mobility and little social fluidity, chances for improved socio-economic standing are limited and hence perceived structural loss and lack of opportunity might lead to more hostility towards immigrants (Benabou and Ok, 2001; Alesina et al., 2018). By contrast, living in a context of expanding economies and equality of opportunity widens opportunities for upward mobility in general and as such provides a context which can influence individual aspirations and expectations to get ahead in life. Mobility context can thus be expected to influence the attitudes of young people that are directly influenced by the opportunities available; however, mobility context might also influence older people who are concerned about their children's opportunities or the state of the country overall. We are not aware of any studies that have looked at the role of mobility context for individual attitudes towards immigrants. With cumulative data from the European Social Survey, we are now in a unique position where absolute and relative intergenerational social mobility rates can be calculated for a large number of countries in Europe (Bukodi et al., 2020).

By incorporating intergenerational social mobility into the explanatory framework of attitudes to immigration, our contribution is also to expand the understanding of micro and macro drivers of individual attitudes towards immigration (Hainmueller and Hopkins, 2014). Explanations for attitudes against migrants generally focus on cultural threat to a country's way of life as well as 'realistic' or economic aspects of threat that include competition on the labor market (Hjerm and Nagayoshi, 2011) and wider economic conditions (Quillian, 1995). Our contribution is to add to the economic framework and investigate the role of intergenerational loss. On the individual level, intergenerational downward mobility can be seen as a novel and a more direct way to capture socioeconomic 
loss and decline than the more static indicators included in other studies, such as, level of education or class position. On the macro level, mobility rates capture changes in opportunity structures between generations and aggregate levels of equality of opportunity, elements not captured with measures like unemployment rates or gross domestic product.

How individuals think and feel about migrants is a salient issue and one that features in political agendas across societies. Policy makers and the general public are variously interested in attracting migrants (e.g. workers who are high-skilled or workers who support welfare states strained by aging populations), deterring migrants (e.g. those from poorer countries or from some religious and cultural backgrounds), and better integrating migrants in their respective societies. Immigration is an important issue across Europe, even in countries where net immigration is relatively low. While the European Union as a major supranational institution actively facilitates and legally supports the free movement of workers, immigration from outside the EU is also a central concern. This makes Europe an ideal setting for our comparative purposes.

For our analysis, we make use of European Social Survey (ESS) data. We pool ESS data from rounds 1 to 5 (ESS, 2002, 2004, 2006, 2008, 2010) and we use a newly validated measure of social origins based on parents' social class position (Bukodi et al., 2020). For macro-level mobility effects, we make use of recent findings that show how mobility rates differ across countries in Europe, thus providing variation for empirical enquiry (Bukodi and Paskov, 2018; Bukodi et al., 2020). We argue that aggregate rates of absolute mobility are an indicator for the opportunities that are available in the society, thus revealing more about the lived experience of status attainment and competition. Relative mobility, however, indicates equality of opportunity in a given society. For investigating social mobility on the individual level, we apply diagonal reference models that allow the effects of the mobility trajectory to be disentangled from origin class and destination class. To study the contextual effects of social mobility, we use random-effects meta-regression models.

Our findings show that there is little evidence that the experience of downward social class mobility, in itself, has a particular influence on attitudes towards immigration, apart from in a few countries. Generally, a failure to do better than one's parents does not make people more hostile towards immigration. Furthermore, we find little evidence in line with the narrative that blocked opportunities in a context as a whole - in terms of low relative mobility rateare at the heart of attitudes towards immigration. However, people living in contexts with high downward mobility rates and low upward mobility rates, in absolute terms, are indeed more negative towards immigration. This suggests that limited opportunities for upward mobility might contribute to the feelings of frustration and hostility towards outsiders. 


\section{Theory and hypotheses}

\section{Social class and intergenerational loss}

Intergenerational class mobility is a core topic in social stratification and mobility research. Social class captures where people stand in the labor market and production units (Goldthorpe, 2007; Wright, 1997). The central argument is that social class positions reflect people's command over economic resources, including life-time earnings, economic security, employment conditions, and so forth (Erikson and Goldthorpe, 1992; Goldthorpe, 2007; Wright, 1997). As a consequence, class is seen as a measure of socioeconomic standing and an indicator of desirability of labour market positions more broadly (Breen, 1997). At the top of the class hierarchy are the economically advantaged positions, typically including employers, managers, and professionals, and at the bottom of the class hierarchy are the economically disadvantaged working classes.

Intergenerational social mobility researchers are interested in how people are faring compared to their parents. Comparing the social class position of parents to that of their offspring gives us information about intergenerational mobility. Some people attain the same class position as their parents, they are thus stable or immobile. When people end up in a lower social class position than their parents, they are considered downwardly mobile. When people end up in a higher class position than their parents, they are considered upwardly mobile. Downward mobility is likely to be experienced as loss and decline in terms of socioeconomic standing, whereas upward mobility will be experienced as improvement of socioeconomic standing compared to one's parents. An important question is whether the experience of intergenerational social class mobility or mobility context one lives in make a difference for individual's attitudes and behavior (Lipset and Bendix, 1959).

\section{Intergenerational loss and attitudes towards immigrants: micro-mechanisms}

Since social class positions are sources of varying socioeconomic advantages and disadvantages, they are commonly linked with attitudinal and behavioural outcomes (Brooks and Svallfors, 2010; De Graaf et al., 1995; De Regt et al., 2012). For example, the working classes are in disadvantaged economic circumstances and may be more likely to compete with immigrants (or more likely to perceive themselves to be in competition with immigrants) in occupational classes or particular industries where immigrants are over-represented. From this perspective, economic competition can explain why the working classes hold stronger anti-immigration views compared to those in the upper classes (Quillian, 1995; Tolsma et al., 2007; Hjerm and Nagayoshi, 2011). We also know 
that attitudes towards immigrants or politics are not only influenced by one's own class position but also the social class of origin or parental class (Dalhouse and Frideres, 1996; De Graaf et al., 1995; Tolsma et al., 2009). While economic circumstances and material self-interests are the most common mechanisms put forward to explain why class matters for attitudinal outcomes, different social networks, socialisation, and (cultural) contexts that social classes are exposed to can play a role as well in shaping attitudes (De Regt et al., 2012; Brooks and Svallfors, 2010).

The specific interest of this study, however, is not one's social class position or class background, but the experience of intergenerational social class mobility. We focus on whether intergenerational loss - being downwardly mobile - is associated with attitudes towards immigrants. According to sociological theory, parents serve as an important point of reference for their children and this comparison will be relevant throughout one's life (Barg, 2019; Breen, 1997; Chetty et al., 2017; Goldthorpe, 1987; Hout and DiPrete, 2006; Raftery and Hout, 1993). Much of this literature refers to people's aversion of downward mobility and that families aim for their children to do better or at least equally good as their parents, but certainly not worse. What this implies then is that when status reproduction has not been successful people should feel a sense of loss and decline or relative deprivation. Conversely, reproducing parental position or doing better than one's parents are seen as positive outcomes because either status maintenance or upward mobility are achieved (Breen, 1997).

However, little is known how exactly people interpret their gains and losses, and what are the implications of mobility experiences on attitudinal or behavioural outcomes. If people do interpret downward social mobility as a form of social decline or loss, then those experiencing loss are likely to be frustrated. The post-liberal theory of stratification proposed by Jackson and Grusky (2018) and scapegoat theory (Hammer, 2007; Semyonov et al., 2006) suggest that one possible way to channel frustrations stemming from economic loss and decline is to blame someone else for it. Immigrants can be blamed because they are perceived as direct competitors for jobs. For example, someone from intermediate class background ending up in the working class position might blame immigrants for increased competition for intermediate class jobs. However, frustration stemming from economic loss and downward mobility might be targeted against immigrants even if they are not the actual reason behind economic losses. We know that immigrants are more likely to hold working class jobs and hence they should not be the reason why the natives are downwardly mobile. However, as scapegoat theory suggests, blaming outsiders might simply serve the psychological need to channel frustrations towards an outside group. Furthermore, politicians and the media can contribute to framing immigrants as the ones to blame for native populations economic loss and decline even if there 
is little evidence that this would actually be the case (O'Flynn et al., 2014).

While Tolsma et al. (2009) show that downward mobility does not influence attitudes towards immigrants in the Netherlands, Daenekindt et al. (2018) show that the downwardly mobile in the Dutch society 'blame the system' for their social decline. There are other studies that have focused on social class, mobility, and broader political attitudes but findings regarding the role played by intergenerational loss are mixed (Breen, 2001; De Graaf et al., 1995; Jaime-Castillo and Marqués-Perales, 2019; Paterson, 2008). Several studies have looked at whether downward social mobility is associated with lower well-being or life satisfaction, however, there is no consensus on this question either (Becker and Birkelbach, 2018; Hadjar and Samuel, 2015; Kaiser and Trinh, 2019; Präg and Richards, 2019; Zhao et al., 2017). In this study, we add to this literature by studying the relationship between intergenerational social mobility and attitudes towards immigrants. Our first hypothesis is:

H1: Individuals who have experienced downward mobility show stronger hostility towards immigrants.

\section{Context of loss and attitudes towards immigrants: macro- mechanisms}

Beyond individual-level approaches, macro-sociological theories highlight the different social contexts and opportunity structures that characterise life chances in a given context. First, the absolute mobility rate indicates the extent to which people, on average in a given context, do better or worse than their parents. When many people in a society do worse than their parents (i.e. there is a high rate of downward mobility), this is a sign of limited opportunities to do better than one's parents and indicates downgrading of the occupational structure. A high upward mobility rate, however, is a sign of prosperity and prevailing opportunities. From the perspective of 'prospect effects', living in a context of occupational upgrading - for example, an expanding professional class - improves opportunities as such and provides a context which can influence individual expectations for upward mobility or a perception that there is more room at the top for everyone. This is also known as the prospect of upward mobility (POUM) hypothesis (Benabou and Ok, 2001) or the optimism hypothesis (Alesina et al., 2018). By contrast, in a context where occupational upgrading is limited and downward mobility is high, opportunities for improved social status (for oneself, as well as for others in one's wider social group) are limited and hence perceived relative deprivation, competition, and frustration might increase. Living in a context where social decline is common could thus lead to more hostility towards immigrants. The prospect of downward mobility might create anxiety and fear about loss of status even among those that have 
not been downwardly mobile themselves.

European countries are going through major economic and structural changes triggered by factors such as globalization and rising international competition, skill-biased technological change and increasing automation (Autor, 2015; Goldin and Katz, 2008; Oesch, 2013). These global economic forces have had implications for the occupational structure, including employment and work opportunities for the current generation of workers. Bukodi et al. (2020) show that downward mobility rates in European countries are now much higher than what was reported in earlier studies. In some countries in Europe, half of the population can now be found in less advantaged class positions than their parents while in other countries it is only about a quarter. In this study, we ask whether people living in contexts with high downward mobility are more negative about immigration. Drawing on the macro-sociological theories, our second hypothesis is:

H2: In contexts where downward mobility rates are higher, individuals show stronger hostility towards immigrants.

Second, next to absolute mobility, we consider relative mobility rates in a country. Relative mobility (also known as social fluidity) refers to the strength of an association between the socio-economic position an individual occupies and the position in which he or she was brought up. If the association between parents' and children's social positions is relatively weak, a society is deemed more mobile (i.e. there is more equality of opportunity and social fluidity) (Erikson and Goldthorpe, 1992). In contexts where relative mobility chances are low, there are fewer legitimate opportunities to achieve success and heightened social class positions. In the face of blocked opportunities and a general sense of inequality of opportunity, people might become frustrated (Merton, 1968). In more fluid contexts, by contrast, chances of ascending the socio-economic hierarchy are more evenly distributed across social origins, which might lead to lower rates of frustration and hostility towards non-natives. Lack of relative mobility might thus be a particular source of frustration because the liberal commitment to equal opportunity has not been realised (Jackson and Grusky, 2018). This leads us to our third hypothesis:

H3: In contexts where there is less relative mobility, individuals show stronger hostility towards immigrants.

\section{Data and methods}

\section{Data: European Social Survey, 2002-10}

Analyses are based on a newly-constructed dataset derived from the pooled data of the European Social Survey (ESS, 2002, 2004, 2006, 2008, 2010). We merge 
the original ESS data with ESS-DEVO data - a product of a project entitled 'Improving the Measurement of Social Background in the European Social Survey' (Ganzeboom, 2013). ESS-DEVO has been specifically designed to provide detailed information on survey respondents' social origins. We pool the first five waves of the ESS that were collected biennially between 2002 and 2010 and restrict the sample to a population in the age-bracket of 30 and 60 years at the time of the data collection. Thereby we include the core working-age population and at the same time we make sure that our respondents have reached their occupational maturity. By definition, the analysis is restricted to those for whom parental class is observed. We also exclude from the sample respondents who were born abroad and respondents with both parents born abroad. This decision is made based on the fact that the class distributions of foreign parents cannot be compared to the class distributions of parents of the native population. Consequently, downward mobility is likely to have a different meaning for someone from the native population compared to someone with an immigrant background. However, in order to ensure that our findings are not biased due to leaving out a rather large group in some countries, we also present an auxiliary analysis including the foreign-born and those with foreign-born parents (see Table A1 in the Appendix).

In total, we include 30 European countries in our analysis for which aggregate mobility data is available (Bukodi et al., 2020). We know from previous research that European countries tend to cluster into more or less distinct sets based on their attitudinal patterns towards immigration, with a sharp divide between Eastern and Western European countries (Kunovich, 2004; Bail, 2008). The more open or favorable attitudes are generally seen in the Western Europe the least favorable in Eastern Europe (Heath and Richards, 2020). To acknowledge the fact that we are dealing with a heterogeneous set of countries, we distinguish Western and Eastern Europe in our analyses. Western European countries include: Austria, Belgium, Cyprus, Denmark, Finland, France, Germany, Greece, Ireland, Italy, Luxembourg, Netherlands, Norway, Portugal, Spain, Sweden, Switzerland, United Kingdom. Eastern European countries include: Bulgaria, Czech Republic, Estonia, Hungary, Latvia, Lithuania, Poland, Romania, Russia, Slovakia, Slovenia, and Ukraine.

Our outcome variable, attitudes towards immigration are measured using an index constructed out of three items: 1) 'Would you say it is generally bad or good for [country]'s economy that people come to live here from other countries?' 2) 'Would you say that [country]'s cultural life is generally undermined or enriched by people coming to live here from other countries?' 3) 'Is [country] made a worse or a better place to live by people coming to live here from other countries? All three items are measured on a scale ranging from 0 to 10 , where 0 stands for (1) 'Bad for the economy', (2) 'Cultural life undermined', or, (3) 
'Worse place to live' and 10 denotes (1) 'Good for the economy', (2) 'Cultural life enriched', or, (3) 'Better place to live'. The index is re-coded so that higher values indicate more negative attitudes towards immigration, and can therefore be interpreted so that higher values indicate hostility towards immigration. While these items have been designed to capture perceptions of realistic threat (item 1) and symbolic threat (item 2), and attitudes towards the presence of immigrants more generally (item 3), we find that in practice respondents are not, on the whole, making these distinctions. The three items correlate at around 0.7 and the Cronbach's alpha is .84 (ranging from .0.76 in Luxembourg to .89 in the United Kingdom), reflecting high internal consistency of the index. The index is intended to capture attitudes that are either generally positive or generally negative towards immigrants (Hepler and Albarracin, 2013). A missing is recorded when one of the items on the scale is missing but the overall missingness on this index is low at just under two per cent. This variable has been used in a number of studies (Polavieja, 2016; Pardos-Prado and Xena, 2019; Schneider, 2008).

Our central explanatory variable is intergenerational social class mobility, we look at both individual mobility and mobility context. We measure mobility by comparing the social class of the respondent to the social class of their parents. We measure social class of both respondents and their parents in terms of the European Socio-Economic Classification (ESEC) (Rose and Harrison, 2010), making a distinction between three class categories: 1) Salariat, 2) Intermediate classes, 3) Working class. In a robustness check, we utilize a five-category class schema. Respondents who were not in employment at the time of interview are allocated to a class position on the basis of their last employment. Again, we conduct a robustness check where the unemployed are a separate category. For defining parental social class, we use the dominance approach, which means that we record the class of the parent (when the respondent was 14) who has the higher-ranking social class position. The individual (micro-level) measure of intergenerational social mobility has three categories. People who are found in a higher social class position than their parents are classified as upwardly mobile and people who are found in lower class than their parents, are classified as downwardly mobile. If an individual is in the same class position as their parents, they are classified as stable (or immobile). Control variables in the micro-models are gender and age of respondents as well as survey round and country. Gender is a particularly relevant variable because women might be more likely to experience downward mobility due to caring responsibilities. To the extent that downward mobility has a different meaning for women than for men, the implications on their attitudes might vary.

In case of macro-level mobility figures, we obtain country-level data on absolute and relative mobility rates from the work done by Bukodi et al. (2020). 
These mobility figures are calculated based on the same pooled ESS 2002-10 data underlying our micro-analysis. Absolute mobility is captured in simple percentage terms and it refers to the proportion of individuals in a country who have moved downwards from their origin positions (i.e. the percentage downwardly mobile) or the proportion of people who have moved upward (i.e. the percentage upwardly mobile). We also consider the ratio between upward and downward mobility to indicate whether it is upward or downward mobility that is more prevalent in a particular context. Absolute mobility tells us something about the opportunity structure, high downward mobility means that many children have moved to lower social class positions compared to their parents. Relative mobility is captured by 'unidiff' and global log odds ratios, two summary measures that capture the strength of the association between individuals' origin and destination positions net of all class structural differences between parents and respondents (for details on these measures, see Bukodi et al., 2020). Both measures are interpreted in the same way, higher values indicate a stronger association between parent's and children's social class and thus less social fluidity and equality of opportunity. These country-level mobility figures are calculated based on a sample of men only because men's mobility rates provide a more consistent measure of opportunity structures in cross-national settings. Women's mobility rates differ across countries due to various national factors, such as the rate of female labor market participation and part-time work (Breen et al., 2010; Bukodi and Paskov, 2020).

In the macro-analysis, in order to rule out potential confounders, we account for two control variables: (a) either GDP per capita in international dollars (averaged across 2002-10) or a logged version of it as a proxy for wealth of a country obtained from the World Bank (2020), and, (b) migrant stock measured by percentage of the population born abroad. We calculated percentage born abroad from the ESS survey taking an average across 2002-10 survey years in a full sample including all ages and applying survey weights. Our measure of immigrant stock has a high degree of consistency with migration figures compiled by the OECD (see Figure A1 in the Appendix), but we choose to generate our own measure in order to get full coverage on all countries in our sample. A correlation matrix with all the macro variables is in Table A4 in the Appendix. Descriptive statistics for all variables are presented in Table 1.

\section{Analytical strategy}

Our analysis proceeds in three parts. First, in a descriptive step, we present average attitudes towards immigration by parental class of origin and respondent's own social class across all countries in our sample. In a second part, we investigate the role of origin and destination class for attitudes towards immigration, stratified by Eastern and Western Europe, and examine the association 
Table 1: Descriptive statistics, $N=97,332$

\begin{tabular}{|c|c|c|c|c|}
\hline & Prop./Mean & $S D$ & Min. & Max. \\
\hline Hostility towards immigration & 4.94 & 2.12 & 0.00 & 10.00 \\
\hline \multicolumn{5}{|l|}{ Respondent social class: } \\
\hline Salariat & 0.34 & & 0.00 & 1.00 \\
\hline Intermediate & 0.29 & & 0.00 & 1.00 \\
\hline Working & 0.37 & & 0.00 & 1.00 \\
\hline \multicolumn{5}{|l|}{ Parental social class: } \\
\hline Salariat & 0.28 & & 0.00 & 1.00 \\
\hline Intermediate & 0.34 & & 0.00 & 1.00 \\
\hline Working & 0.39 & & 0.00 & 1.00 \\
\hline \multicolumn{5}{|l|}{ Mobility: } \\
\hline Downwardly mobile & 0.24 & & 0.00 & 1.00 \\
\hline Stable & 0.47 & & 0.00 & 1.00 \\
\hline Upwardly mobile & 0.29 & & 0.00 & 1.00 \\
\hline Female sex & 0.53 & & 0.00 & 1.00 \\
\hline Age & 45.06 & 8.79 & 30.00 & 60.00 \\
\hline \multicolumn{5}{|l|}{ ESS round: } \\
\hline Round 1 (2002) & 0.17 & & 0.00 & 1.00 \\
\hline Round 2 (2004) & 0.20 & & 0.00 & 1.00 \\
\hline Round 3 (2006) & 0.20 & & 0.00 & 1.00 \\
\hline Round 4 (2008) & 0.23 & & 0.00 & 1.00 \\
\hline Round 5 (2010) & 0.21 & & 0.00 & 1.00 \\
\hline Upward mobility rate & 35.52 & 4.68 & 23.47 & 47.04 \\
\hline Downward mobility rate & 32.83 & 5.43 & 23.67 & 49.59 \\
\hline Ratio between upward and downward mobility & 1.13 & 0.32 & 0.47 & 1.92 \\
\hline Relative mobility (unidiff) & 0.09 & 0.94 & -1.85 & 2.14 \\
\hline Relative mobility (global log odds ratios) & -0.03 & 1.01 & -1.66 & 2.52 \\
\hline GDP per capita & 34374.76 & 12922.77 & 7004.33 & 87209.82 \\
\hline GDP per capita, logged & 10.36 & 0.43 & 8.85 & 11.38 \\
\hline Percentage born abroad & 8.28 & 5.04 & 0.54 & 32.59 \\
\hline$N$ & 97,332 & & & \\
\hline
\end{tabular}


between individual social mobility and attitudes towards immigration. We further address potential heterogeneity between countries by conducting separate analyses for each country. For these analyses, we make use of the diagonal reference models (Van der Waal et al., 2017), a statistical approach for disentangling the effects of origin class, destination class, and mobility trajectory in an upward or downward direction. Social mobility effects are the difference between social class origin and class destination and therefore conventional regression models cannot identify social mobility effects due to collinearity. Instead, diagonal reference models use the socially immobile as a reference group against which the socially mobile are compared to. Specifically, diagonal reference models estimate the effects of origin and destination class on the outcome using a single vector of coefficients for both class positions along with weighting parameters, which represent the relative importance of the origin and destination classes:

$$
Y=a+p * \mu_{i i}+q * \mu_{j j}+b \mathbf{X}
$$

In Equation (1), $a$ is the model intercept. Subscripts $i$ and $j$ represent the social position of origin and destination, respectively. $\mu_{i i}$ and $\mu_{j j}$ are both estimates of $Y$ in the main diagonal. $p$ represents the relative importance of the class of origin, and $q$ the relative importance of the destination class (and $p=1-q) . \mathbf{X}$ is a vector of covariates that can be interpreted like regression coefficients. We use a linear link function for the model.

To estimate the mobility effects, we extend the model with mob, a vector of dummy variables indicating the mobility trajectory of respondents:

$$
Y=a+p * \mu_{i i}+q * \mu_{j j}+b \mathbf{X}+c \mathbf{m o b}
$$

To estimate our diagonal reference models, we make use of Kaiser's (2019) 'drm' command for Stata.

In a third part of our analyses, we examine the context effects of countrylevel mobility indicators. For this, we conduct a two-step multilevel analysis as suggested by Mills and Präg (2016). In a first step, we estimate the average attitude to immigration in a country accounting for compositional differences between countries via country-specific ordinary least squares (OLS) regression, i.e. we account for own and parental social class, age, sex, and survey round. These estimates can then be interpreted as the average attitude to immigration in a country if the class and demographic composition was the same in all countries. In a second step, we correlated these adjusted averages of attitudes to immigration with country-level mobility indicators, first descriptively with bivariate scatterplots, then with the additional control variable logged GDP per capita and with random effects meta-analysis (Harbord and Higgins, 2008), which takes the uncertainty around the adjusted averages of attitudes to immi- 
gration into account.

Our analyses are fully replicable. The data used for our analyses are publicly available and we provide readers with a Stata do-file on-line that allows to replicate all analyses shown in this manuscript (Paskov et al., 2020).

\section{Results}

Social class, social mobility, and attitudes towards immigration

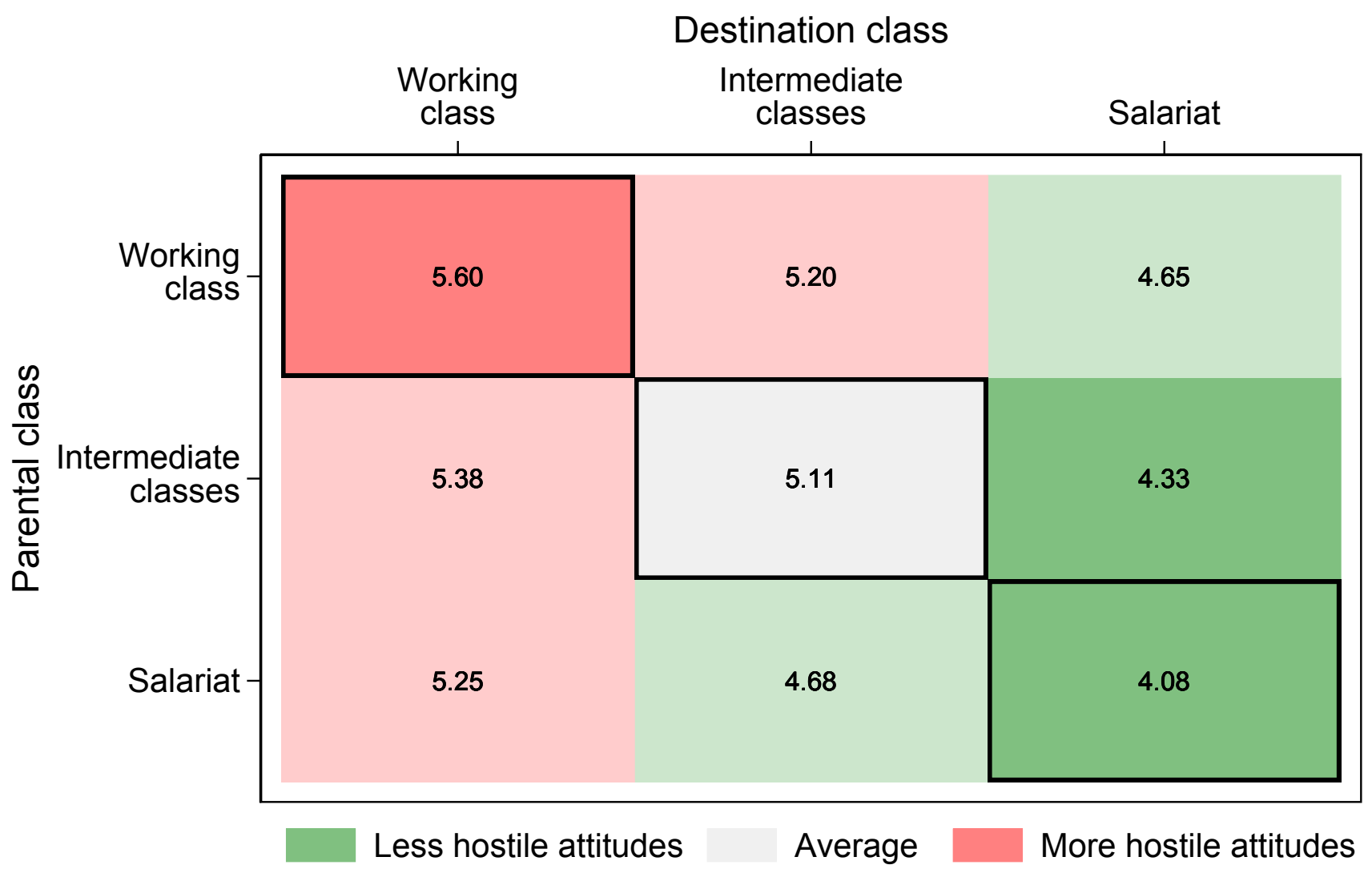

Figure 1: Average scores on hostility towards immigration (scale 0-10) in Europe by social class of origin and destination.

Note: See Präg (2019) for visualization details.

Figure 1 demonstrates that attitudes in the pooled sample follow a clear social class gradient, meaning that people belonging to the working class are 
more hostile towards immigration, this is somewhat less the case for the intermediate social class, and the salariat class appears to be least hostile towards immigration. This social class gradient holds across most countries in Europe (see Figure A2 in the Appendix). Next to social class of destination, social class of origin (i.e. parental class) is also associated with attitudes towards immigration. Figure 1 also illustrates how people who are consistently in the salariat class (both in terms of origin and destination) are least hostile towards immigration, while people that are consistently in the working class have the strongest anti-immigrant attitudes. Lower social class of origin is associated with more negative attitudes towards immigrants and higher social class of origin is associated with more positive attitudes towards immigrants. In order to adequately distinguish class of origin, class of destination, and mobility experience, we now turn to diagonal reference models.

Table 2: Diagonal reference model of hostility towards migrants, stratified by gender and European region

\begin{tabular}{|c|c|c|c|c|c|c|c|c|}
\hline & $\begin{array}{l}\text { Western Europe } \\
\text { Model 1: Men }\end{array}$ & Model 1: Women & Model 2: Men & Model 2: Women & $\begin{array}{l}\text { Eastern Europe } \\
\text { Model 1: Men }\end{array}$ & Model 1: Women & Model 2: Men & Model 2: Women \\
\hline \multicolumn{9}{|l|}{ Immobiles } \\
\hline Salariat & $\begin{array}{c}-0.88^{* * * *} \\
(0.04)\end{array}$ & $\begin{array}{c}-0.85^{* * * *} \\
(0.04)\end{array}$ & $\begin{array}{c}-0.89^{* * * *} \\
(0.04)\end{array}$ & $\begin{array}{c}-0.84^{* * *} \\
(0.04)\end{array}$ & $\begin{array}{c}-0.49^{* * * *} \\
(0.07)\end{array}$ & $\begin{array}{c}-0.41^{* * * *} \\
(0.07)\end{array}$ & $\begin{array}{c}-0.50^{* * *} \\
(0.08)\end{array}$ & $\begin{array}{c}-0.42^{* * * *} \\
(0.08)\end{array}$ \\
\hline Intermediate & $\begin{array}{c}0.17^{* * *} \\
(0.03)\end{array}$ & $\begin{array}{l}0.09^{* * *} \\
(0.03)\end{array}$ & $\begin{array}{c}0.17^{* * *} \\
(0.03)\end{array}$ & $\begin{array}{c}0.08^{* *} \\
(0.03)\end{array}$ & $\begin{array}{c}0.06 \\
(0.06)\end{array}$ & $\begin{array}{c}0.05 \\
(0.05)\end{array}$ & $\begin{array}{c}0.08 \\
(0.10)\end{array}$ & $\begin{array}{c}0.08 \\
0.07)\end{array}$ \\
\hline Working & $\begin{array}{c}0.71^{* * *} \\
(0.04)\end{array}$ & $\begin{array}{l}0.75^{* * * *} \\
(0.05)\end{array}$ & $\begin{array}{c}0.72^{* * *} \\
(0.04)\end{array}$ & $\begin{array}{c}0.76^{* * *} \\
(0.05)\end{array}$ & $\begin{array}{c}0.42^{* * *} \\
(0.06)\end{array}$ & $\begin{array}{c}0.35^{* * *} \\
(0.06)\end{array}$ & $\begin{array}{c}0.42^{* * *} \\
(0.08)\end{array}$ & $\begin{array}{c}0.34^{* * *} \\
(0.06)\end{array}$ \\
\hline \multicolumn{9}{|l|}{ Origin weight } \\
\hline Origin weight & $\begin{array}{c}0.29 \\
(0.02)\end{array}$ & $\begin{array}{c}0.36 \\
(0.02)\end{array}$ & $\begin{array}{c}0.30 \\
(0.05)\end{array}$ & $\begin{array}{c}0.29 \\
(0.04)\end{array}$ & $\begin{array}{c}0.29 \\
(0.06)\end{array}$ & $\begin{array}{c}0.36 \\
(0.04)\end{array}$ & $\begin{array}{c}0.42 \\
(0.16)\end{array}$ & $\begin{array}{c}0.57 \\
(0.13)\end{array}$ \\
\hline \multicolumn{9}{|l|}{ Covariates } \\
\hline Age (centered) & $\begin{array}{c}0.00 \\
(0.00)\end{array}$ & $\begin{array}{l}0.00^{* *} \\
(0.00)\end{array}$ & $\begin{array}{c}0.00 \\
(0.00)\end{array}$ & $\begin{array}{l}0.00^{* *} \\
(0.00)\end{array}$ & $\begin{array}{c}0.01^{* * * *} \\
(0.00)\end{array}$ & $\begin{array}{c}0.01^{* * *} \\
(0.00)\end{array}$ & $\begin{array}{c}0.01^{* * * *} \\
(0.00)\end{array}$ & $\begin{array}{c}0.01^{* * * *} \\
(0.00)\end{array}$ \\
\hline \multicolumn{9}{|l|}{ Mobility parameters (ref. upward) } \\
\hline Downwardly mobile & & & $\begin{array}{l}-0.00 \\
(0.12)\end{array}$ & $\begin{array}{l}-0.13 \\
(0.10)\end{array}$ & & & $\begin{array}{c}0.17 \\
(0.17)\end{array}$ & $\begin{array}{c}0.24 \\
(0.14)\end{array}$ \\
\hline Stable & & & $\begin{array}{c}0.05 \\
(0.07)\end{array}$ & $\begin{array}{l}-0.06 \\
(0.06)\end{array}$ & & & $\begin{array}{c}0.07 \\
(0.13)\end{array}$ & $\begin{array}{c}0.16 \\
(0.09)\end{array}$ \\
\hline Constant & $\begin{array}{l}5.01^{* * * *} \\
(0.04)\end{array}$ & $\begin{array}{l}4.98^{* * *} \\
(0.05)\end{array}$ & $\begin{array}{l}4.99^{* * *} \\
(0.08)\end{array}$ & $\begin{array}{l}5.04^{* * *} \\
(0.07)\end{array}$ & $\begin{array}{c}4.40^{* * *} \\
(0.28)\end{array}$ & $\begin{array}{c}4.49^{* * *} \\
(0.19)\end{array}$ & $\begin{array}{l}4.33^{* * *} \\
(0.25)\end{array}$ & $\begin{array}{l}4.35^{* * *} \\
(0.14)\end{array}$ \\
\hline Country dummies included & Yes & Yes & Yes & Yes & Yes & Yes & Yes & Yes \\
\hline Survey round dummies included & Yes & Yes & Yes & Yes & Yes & Yes & Yes & Yes \\
\hline Observations & 32,007 & 34,064 & 32,007 & 34,064 & 14,225 & 17,036 & 14,225 & 17,036 \\
\hline AIC & 132275.9 & 137877.1 & 132274.4 & 137878.1 & 61016.4 & 72263.4 & 61018.8 & 72262.2 \\
\hline $\mathrm{BIC}$ & 132351.3 & 137953.0 & 132366.6 & 137970.9 & 61084.4 & 72333.1 & 61102.0 & 72347.4 \\
\hline
\end{tabular}

Table 2 shows the results of a diagonal reference model (DRM). Here, we make a distinction between Western and Eastern Europe and men and women. In Model 1, social class estimates parameters for the socially immobile, i.e. those in the same social class as their parents. Here, results confirm that a social class gradient exists in attitudes towards immigration. People who are stably in the working class (i.e. they are in the working class and their parents are/were in the working class) are more likely to report negative attitudes towards immigration. People stably in the salariat, however, are less hostile towards immigration. This 
holds for men and women and people in Western and Eastern Europe net of age, survey round, and country.

Another parameter of interest in Model 1 in Table 2 is the origin weight, which shows the relative influence of origin and destination class on the outcome variable. The origin weight in our analysis ranges from 0.29 to 0.36 , suggesting that parental social class contributes a third of the total class effect on attitudes towards migration. The origin weight is similar in the Western and Eastern Europe and for men and women. This indicates that though one's class of destination matters more than social class of origin, parental social class will continue to exert an effect on attitudes in adulthood even after accounting for individual's own social class position, perhaps through socialization processes.

However, our main interest is the role played by mobility experience, which we introduce in Model 2 of Table 2. This is to test for the net effect of intergenerational class mobility over and above the effect of one's class of origin or destination. The estimates for social class are substantively small and do not reach statistical significance, suggesting that social class mobility does not matter for how people feel about immigration. Those who are doing worse than their parents or are in the same position as their parents are not more negatively oriented towards immigration as compared to those that have been upwardly mobile. This conclusion holds for men and women and both in Western and Eastern Europe. We conclude that there is no support for Hypothesis 1, which posited that individuals who have experienced downward mobility show stronger hostility towards immigrants. The findings from Table 2 are robust to alternative definitions of social class, a measure of class that adds the unemployed as a separate category (Table A1) or a more detailed measure distinguishing five categories of class instead of three (Table A2). The findings also hold when we expand our sample to people that were born abroad or had both parents born abroad (Table A3).

Are the findings in Table 2 masking heterogeneity between the 30 countries in our sample? Figure 2 shows origin weights and effects for being downwardly mobile or immobile for each country in our sample. In these models we control for gender and age but also survey year. When it comes to origin weight, we see that in most countries destination class is more important than origin class. Yet there is some variation across countries: while in some countries origin class accounts for less than a quarter of variation in attitudes towards immigration, in other countries it accounts for half of the variation. It appears thus that in some countries the role of social origin is more important (e.g. Lithuania, Poland, Austria) while it other countries parental social class matters much less (e.g. Estonia, Spain, Sweden, Finland). Thus, both social class of origin and destination matter for attitudes towards immigration, albeit with some variation across countries. 

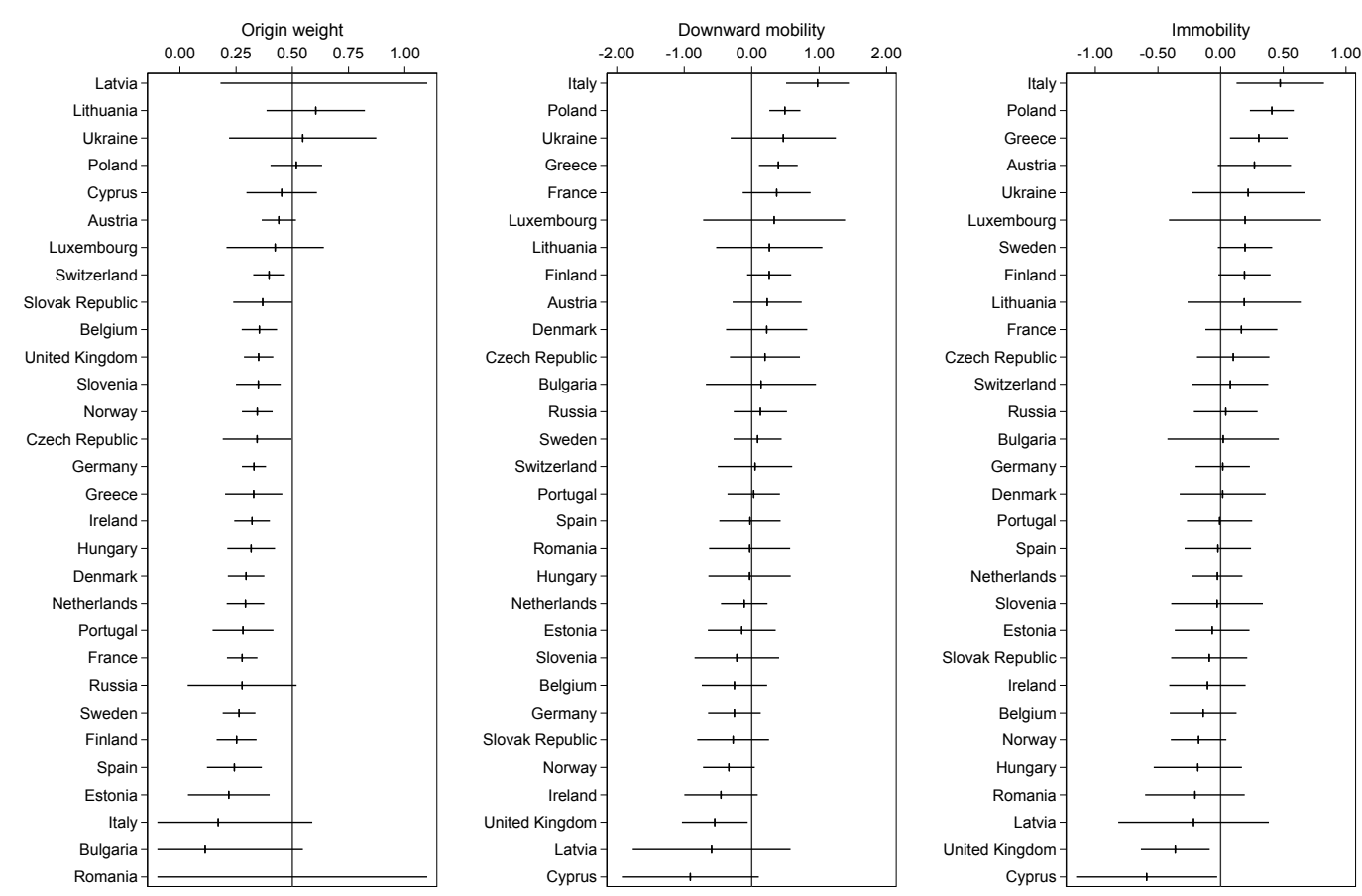

Figure 2: Origin weights and 95\% confidence intervals from country-specific diagonal reference models controlling for gender, age, and survey round. 
Figure 2 also shows the coefficients from country-specific models for downwardly mobile and immobile individuals, again, revealing some heterogeneity across countries. While in most countries parameters of being downwardly mobile or immobile compared to being upwardly mobile are not significantly linked with more (or less) hostility towards immigration, there are some cases where mobility matters. In Italy, Poland, and Greece being downwardly mobile or immobile is associated with stronger anti-immigration attitudes. In the United Kingdom, the opposite is the case, being downwardly mobile or stable is associated with less hostility towards immigration. Considering that mobility experience does not matter in most countries, we conclude that there is very little evidence for Hypothesis 1, which suggested that individuals who have experienced downward mobility show stronger hostility towards immigrants.

\section{The role of social mobility context}

Up to now we examined whether the experience of social mobility is linked with attitudes towards immigration. Next, we look at whether mobility context is linked with how people feel about immigration. To answer this question, we estimated country-specific OLS regression models controlling for age, gender, survey round, and own and parental social class. From these models we obtained hypothetical average anti-immigration attitudes which assume that all societies have the same age, gender, survey round, and own and parental position distributions. We correlate these averages with several indicators of social mobility, namely upward and downward mobility rates, the ratio between upward and downward mobility rate, two indicators of relative mobility, logged and unlogged GDP per capita, and migrant stock measured as the percentage of individuals born abroad. Figure 3 shows the associations. Upward and downward mobility rates and the ratio between them are all correlated with anti-immigration attitudes, as is GDP per capita. In countries where there is more downward mobility and less upward mobility attitudes towards immigration, on average, are more hostile. The same holds for countries which are poorer. When it comes to relative mobility, i.e. equality of opportunity, the association is much weaker. The association between anti-immigrant attitude and a proxy for migrant stock (i.e. percentage born abroad) is also weak.

A more conservative test of these relationships are the random-effects metaregression models presented in Table 3. These models take the standard errors of the hypothetical average anti-immigration attitudes into account. Each column in Table 3 is dedicated to different mobility indicators as predictors and presents three separate models controlling for (1) GDP per capita (logged), (2) Percentage of foreign born, or, (3) GDP per capita (logged) and Percentage foreign born. The findings show that more downward mobility is associated with more hostile attitudes towards immigration both after controlling for GDP 

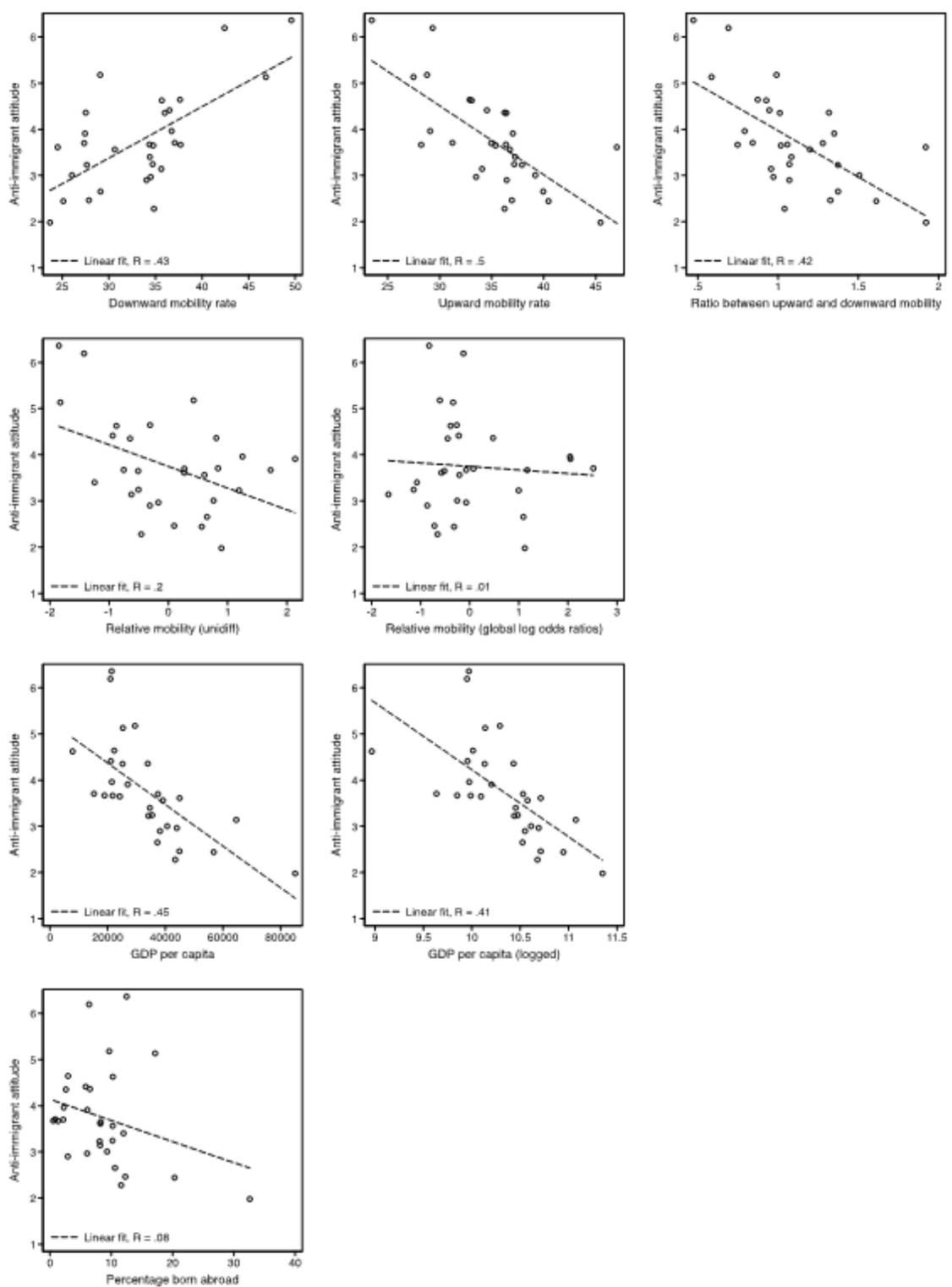

Ratio between upward and downward mobalty 
Table 3: Random effects meta-regression models predicting hostility towards immigration, each column presents three separate models with a different mobility indicator as a predictor (indicated in the first row) and controlling for (1) Models 1: GDP per capita (logged), (2) Models 2: Percentage foreign born, (3) Models 3: GDP per capita (logged) and Percentage foreign born.

\begin{tabular}{|c|c|c|c|c|c|}
\hline & Downward mobility rate & Upward mobility rate & Updown & Unidiff & Global log odds \\
\hline \multicolumn{6}{|l|}{ Model 1} \\
\hline \multirow[t]{2}{*}{ Mobility predictor } & $0.07^{* *}$ & $-0.10^{* *}$ & $-1.23^{*}$ & $-0.33^{*}$ & -0.24 \\
\hline & $(0.03)$ & $(0.03)$ & $(0.53)$ & $(0.15)$ & $(0.15)$ \\
\hline \multirow[t]{2}{*}{ GDP per capita (logged) } & $-0.92^{*}$ & $-0.80^{*}$ & $-0.89^{*}$ & $-1.30^{* *}$ & $-1.58^{* * *}$ \\
\hline & $(0.35)$ & $(0.36)$ & $(0.39)$ & $(0.31)$ & $(0.33)$ \\
\hline \multicolumn{6}{|l|}{ Model 2} \\
\hline \multirow[t]{2}{*}{ Mobility predictor } & $0.11^{* * *}$ & $-0.15^{* * *}$ & $-1.98^{* * *}$ & $-0.49^{* *}$ & -0.12 \\
\hline & $(0.02)$ & $(0.03)$ & $(0.50)$ & $(0.17)$ & $(0.19)$ \\
\hline \multirow[t]{2}{*}{$\%$ foreign-born } & -0.02 & -0.01 & -0.00 & -0.05 & -0.05 \\
\hline & $(0.02)$ & $(0.02)$ & $(0.03)$ & $(0.03)$ & $(0.03)$ \\
\hline \multicolumn{6}{|l|}{ Model 3} \\
\hline \multirow[t]{2}{*}{ Mobility predictor } & $0.07^{*}$ & $-0.11^{* *}$ & $-1.29^{*}$ & $-0.33^{*}$ & -0.23 \\
\hline & $(0.03)$ & $(0.03)$ & $(0.54)$ & $(0.15)$ & $(0.16)$ \\
\hline \multirow[t]{2}{*}{ GDP per capita (logged) } & $-0.97^{*}$ & $-0.91^{*}$ & $-1.00^{*}$ & $-1.27^{* *}$ & $-1.63^{* * *}$ \\
\hline & $(0.41)$ & $(0.38)$ & $(0.42)$ & $(0.38)$ & $(0.38)$ \\
\hline \multirow[t]{2}{*}{$\%$ foreign-born } & 0.01 & 0.02 & 0.02 & -0.00 & -0.01 \\
\hline & $(0.03)$ & $(0.03)$ & $(0.03)$ & $(0.03)$ & $(0.03)$ \\
\hline Observations & 30 & 30 & 30 & 30 & 30 \\
\hline
\end{tabular}

or after controlling for percentage of the migrant population but also when controlling for both of them simultaneously. Upward mobility is linked with less hostile attitudes towards immigrants. When there is more downward mobility relative to upward mobility, anti-immigration attitudes are stronger. These findings provide support for Hypothesis 2, which posited that in contexts where downward mobility rates are higher, individuals show stronger hostility towards immigrants.

Counter to expectations, we find that countries that have less relative mobility as indicated by higher 'unidiff' scores (i.e. there is a stronger relationship between parent's and children's class), attitudes towards immigrants are less hostile. However, this does not hold with an alternative measure of relative mobility, global log odds. Taken together, there is mixed evidence regarding the relationship between relative mobility and attitudes towards immigration. We reject Hypothesis 3 because there is no evidence that in contexts where there is less relative mobility, individuals show stronger hostility towards immigrants.

\section{Discussion}

Recent political trends in Europe, as witnessed by rising support for radical right-wing political parties, along with the shock successes at the ballot box 
for Brexit and the Donald Trump presidency, can be interpreted as a backlash against immigration. A popular narrative has emerged suggesting that such trends could be explained by social and economic loss. In this study, we investigated this narrative by looking at whether intergenerational loss is linked with attitudes towards immigration. We took into account both the experience of intergenerational loss on the individual level - doing worse than one's parents in social class terms - but also the role played by the mobility context - how much intergenerational mobility is there in a society overall.

Our study demonstrates, as other studies have done before, that there is a clear social class gradient in attitudes towards immigration. It appears that the working class holds more negative attitudes towards immigration while those in the salariat class are more positive about immigration. To the extent that immigration introduces competition on the labour market, the working classes might feel more economically threatened and hence oppose immigration. However, the social class gradient might also be linked to cultural explanations. Social class also defines cultural values and beliefs, including eagerness to defend national identity (Haubert and Fussell, 2006). Again confirming prior research, next to one's current social class, social class of origin matters as well. Those from working class family backgrounds are more hostile towards immigration as compared to those from salariat class backgrounds. This illustrates that family background continues to play a role in people's attitudes in adulthood and independent of the class position one has attained. This points to the cultural explanation, it is plausible that parents pass on certain values and attitudes to their children. Although family background also defines one's economic security and it could be that those from more disadvantaged backgrounds are more attuned to potential and perceived economic threats posed by immigration. Future research ought to disentangle the mechanisms that explain the role of social origin in defining attitudes in adulthood.

Importantly, we were interested in whether downward mobility experience is associated with more hostility towards immigrants. However, while there is a strong sense in the sociological literature that downward mobility experience is a form of social and economic loss and should therefore be a frustrating experience, we do not find that the downwardly mobile in European countries are more hostile towards immigration than those that have been upwardly mobile or stable in their parental class. In most countries in Europe, individuals that are downwardly mobile from their parental class or stable in their parental class do not feel any differently about immigrants than those that have experienced upward mobility. Only in a few countries, Italy, Greece, and Poland, it seems that the downwardly mobile are more hostile towards immigration. The results thus suggest that it is the social class of origin and destination that matter for attitudes towards immigration, and not (in most countries) the experience of 
class mobility in itself.

Next to individual mobility experience, we examined the role of mobility context to capture countries that have experienced losses in terms of occupational downgrading and downward mobility. We find that people living in contexts of loss (i.e. in countries with high rate of downward mobility compared to upward mobility) are more negative towards immigrants. This suggests that limited opportunities for upward mobility might contribute to the feelings of frustration and hostility towards outsiders as the post-liberal theory of stratification and scapegoat theory would predict. This positive association between downward mobility and hostility towards immigrants holds after accounting for economic prosperity in a country and migrant stock. However, it is not the case that in societies with more equality of opportunity people are more tolerant and accepting of immigrants. Relative mobility does not seem to be associated with more positive attitudes towards immigration.

This study makes an important contribution to the current popular debates around public attitudes towards immigration, especially the narrative of the role of loss and decline fostering hostile attitudes. Our results are also relevant for the sociological literature, where the consequences of intergenerational social mobility - both the individual experience of mobility and the mobility contextare of central interest. While the role of mobility experience for various outcomes has been more widely researched, studies capturing the role of mobility context are scarce, making our study an important addition to the literature. Although our analysis was restricted due to a relatively small number of countries for which aggregate mobility figures are available, our study is a step towards taking mobility context as a relevant societal-level variable to be considered in future studies.

However, why do we not see that those that have been downwardly mobile from their parental class are more sceptical of immigrants? One explanation could be that downwardly mobile individuals simply do not associate immigrants with their experience of downward mobility. This would cast doubt on the idea that immigrants are scapegoats for the downwardly mobile natives. Future research could investigate whether attitudes towards immigrants are more hostile in contexts where immigrants are well-educated and compete for upper-class jobs, thereby causing downward mobility chances for the natives to increase. Another explanation could be that intergenerational downward mobility in class terms does not define people's sense of loss and decline as much as the literature would lead us to think it does. Instead, people might care more about intragenerational mobility (i.e. one's chances to move ahead during one's life course) than intergenerational social mobility. People might also consider other reference groups more relevant for evaluating trends in their living conditions, for example, peers in one's own or other countries, instead of one's 
parents. Furthermore, it might be that it is not at all the actual social decline that matters but rather the perceived decline or perceived threat of a decline that makes a difference (Engler and Weisstanner, 2020). Jackson and Grusky (2018) talk about loss in terms of losing one's rent-extraction ability or being part of the group that is losing out on former privileges. Hence, what we need to be asking is what does intergenerational mobility in terms of social class actually indicate and whether this is the dimension along which people define their individual success and failure in life. The question is also whether people see loss and failure as an individual or a group phenomenon (Gidron and Hall, 2017; Hainmueller and Hopkins, 2014). This study suggests that it is not one's experience of downward mobility but the context of downward mobility that is associated with attitudes towards immigrants. Interestingly, however, relative mobility rates - or inequality of opportunity - does not seem to be associated with hostility towards immigration, potentially suggesting that it is more the absolute mobility people notice than relative mobility. While the claim in the literature is that a sense of loss and decline is what drives frustration, we need more research on what exactly matters for how people interpret and perceive their socioeconomic gains and losses, and what implications these experiences and perceptions have on attitudinal and behavioural outcomes.

\section{References}

Alesina, Alberto, Stefanie Stantcheva, and Edoardo Teso, 2018. 'Intergenerational Mobility and Preferences for Redistribution.' American Economic Review 108(2): 521-54. doi: 10.1257/aer.20162015.

Autor, David H., 2015. 'Why Are There Still So Many Jobs? The History and Future of Workplace Automation.' Journal of Economic Perspectives 29(3): 3-30. doi: 10.1257/jep.29.3.3.

Bail, Christopher A., 2008. 'The Configuration of Symbolic Boundaries against Immigrants in Europe.' American Sociological Review 73(1): 37-59. doi: 10.1177/000312240807300103.

Barg, Katherin, 2019. 'Why Are Middle-Class Parents More Involved in School than Working-Class Parents?' Research in Social Stratification and Mobility 59: 14-24. doi: 10.1016/j.rssm.2018.12.002.

Becker, Dominik and Klaus Birkelbach, 2018. 'Social Mobility and Subjective Wellbeing Revisited. The Importance of Individual Locus of Control.' Research in Social Stratification and Mobility 54: 1-20. doi: 10.1016/j.rssm.2018.01.001. 
Benabou, Roland and Efe A. Ok, 2001. 'Social Mobility and the Demand for Redistribution. The POUM Hypothesis.' Quarterly Journal of Economics 116(2): 447-487. doi: 10.1162/00335530151144078.

Breen, Richard, 1997. 'Risk, Recommodification, and Stratification.' Sociology 31(3): 473-489. doi: 10.1177/0038038597031003006.

_ 2001. 'Social Mobility and Constitutional and Political Preferences in Northern Ireland.' British Journal of Sociology 52(4): 621-645. doi: 10.1080/00071310120084508.

Breen, Richard and John H. Goldthorpe, 1997. 'Explaining Educational Differentials. Towards a Rational Action Theory.' Rationality and Society 9(3): 275-305. doi: 10.1177/104346397009003002.

Breen, Richard, Ruud Luijkx, Walter Müller, and Reinhard Pollak, 2010. 'Long-Term Trends in Educational Inequality in Europe. Class Inequalities and Gender Differences.' European Sociological Review 26(1): 31-48. doi: $10.1093 / \mathrm{esr} / \mathrm{jcp} 001$.

Brooks, Clem and Stefan Svallfors, 2010. 'Why Does Class Matter? Policy Attitudes, Mechanisms, and the Case of the Nordic Countries.' Research in Social Stratification and Mobility 28(2): 199-213. doi: 10.1016/j.rssm.2010.01.003.

Bukodi, Erzsébet, John H. Goldthorpe, Lorraine Waller, and Jouni Kuha, 2015. 'The Mobility Problem in Britain. New Findings from the Analysis of Birth Cohort Data.' British Journal of Sociology 66(1): 93-117. doi: 10.1111/14684446.12096.

Bukodi, Erzsébet and Marii Paskov, 2018. 'Income Inequality, Living Standards, and Intergenerational Social Mobility.' In Nolan, Brian, ed., Generating Prosperity for Working Families in Affluent Countries, pp. 335-355. Oxford: Oxford University Press. doi: 10.1093/oso/9780198807056.003.0013.

—_ 2020. 'Intergenerational Class Mobility among Men and Women in Europe. Gender Differences or Gender Similarities?' European Sociological Review 36(4): 495-512. doi: 10.1093/esr/jcaa001.

Bukodi, Erzsébet, Marii Paskov, and Brian Nolan, 2020. 'Intergenerational Class Mobility in Europe. A New Account.' Social Forces 98(3): 941-972. doi: $10.1093 / \mathrm{sf} / \mathrm{soz} 026$.

Chetty, Raj, David Grusky, Maximilian Hell, Nathaniel Hendren, Robert Manduca, and Jimmy Narang, 2017. 'The Fading American Dream. Trends in Absolute Income Mobility since 1940.' Science 356(6336): 398-406. doi: 10.1126/science.aal4617. 
Daenekindt, Stijn, Jeroen van der Waal, and Willem de Koster, 2018. 'Social Mobility and Political Distrust. Cults of Gratitude and Resentment?' Acta Politica 53(2): 269-282. doi: 10.1057/s41269-017-0050-4.

Dalhouse, Marie and James S. Frideres, 1996. 'Intergenerational Congruency. The Role of the Family in Political Attitudes of Youth.' Journal of Family Issues 17(2): 227-248. doi: 10.1177/019251396017002005.

De Graaf, Nan Dirk, Paul Nieuwbeerta, and Anthony Heath, 1995. 'Class Mobility and Political Preferences. Individual and Contextual Effects.' American Journal of Sociology 100(4): 997-1027. doi: 10.1086/230607.

De Regt, Sabrina, Tim Smits, and Dimitri Mortelmans, 2012. 'The Relevance of Class in Shaping Authoritarian Attitudes. A Cross-National Perspective.' Research in Social Stratification and Mobility 30(3): 280-295. doi: 10.1016/j.rssm.2012.03.001.

Engler, Sarah and David Weisstanner, 2020. 'The Threat of Social Decline. Income Inequality and Radical Right Support.' Journal of European Public Policy doi: 10.1080/13501763.2020.1733636.

Erikson, Robert and John H. Goldthorpe, 1992. The Constant Flux. A Study of Class Mobility in Industrial Societies. Oxford: Clarendon.

Ersanilli, Evelyn and Patrick Präg, 2020. 'Fixed-Term Work Contracts and Anti-Immigration Attitudes. A Novel Test of Ethnic Competition Theory.' Socarxiv doi: 10.31235/osf.io/42xbp.

ESS, 2002. European Social Survey Round 1. Bergen: NSD Norwegian Center for Research Data. doi: 10.21338/NSD-ESS1-2002.

— , 2004. European Social Survey Round 2. Bergen: NSD Norwegian Center for Research Data. doi: 10.21338/NSD-ESS2-2004.

—_, 2006. European Social Survey Round 3. Bergen: NSD Norwegian Center for Research Data. doi: 10.21338/NSD-ESS3-2006.

—_, 2008. European Social Survey Round 4. Bergen: NSD Norwegian Center for Research Data. doi: 10.21338/NSD-ESS4-2008.

—_, 2010. European Social Survey Round 5. Bergen: NSD Norwegian Center for Research Data. doi: 10.21338/NSD-ESS5-2010.

Ganzeboom, Harry B. G., 2013. ISCO-88 Codes for Parental Occupations in the European Social Survey Rounds 1-5. Amsterdam: VU University.

Gest, Justin, 2016. The New Minority. White Working Class Politics in an Age of Immigration and Inequality. Oxford: Oxford University Press. 
Gidron, Noam and Peter A. Hall, 2017. 'The Politics of Social Status. Economic and Cultural Roots of the Populist Right.' British Journal of Sociology 68(S1): S57-S84. doi: 10.1111/1468-4446.12319.

Goldin, Claudia D. and Lawrence F. Katz, 2008. The Race between Education and Technology. Cambridge, MA: Belknap.

Goldthorpe, John H., 1987. Social Mobility and Class Structure in Modern Britain. Oxford: Clarendon, 2nd edition.

_ - 2007. 'Social Class and the Differentiation of Employment Contracts.' In On Sociology, volume 2 ('Illustration and Retrospect'), pp. 101-124. Stanford, CA: Stanford University Press, 2nd edition.

Grätz, Michael, Kieron Barclay, Øyvind N. Wiborg, Torkild H. Lyngstad, Aleksi Karhula, Jani Erola, Patrick Präg, Thomas Laidley, and Dalton Conley, 2019. 'Universal Family Background Effects on Education Across and Within Societies.' Stockholm Research Reports in Demography 2019(13). doi: 10.17045/sthlmuni.7999148.v1.

Hadjar, Andreas and Robin Samuel, 2015. 'Does Upward Social Mobility Increase Life Satisfaction? A Longitudinal Analysis Using British and Swiss Panel Data.' Research in Social Stratification and Mobility 39: 48-58. doi: 10.1016/j.rssm.2014.12.002.

Hainmueller, Jens and Daniel J. Hopkins, 2014. 'Public Attitudes Toward Immigration.' Annual Review of Political Science 17: 225-249. doi: 10.1146/annurev-polisci-102512-194818.

Hammer, Elliott D., 2007. 'Scapegoat Theory.' In Baumeister, Roy F. and Kathleen D. Vohs, eds., Encyclopedia of Social Psychology, pp. 778-779. Thousand Oaks, CA: Sage. doi: 10.4135/9781412956253.n465.

Harbord, Roger M. and Julian P.T. Higgins, 2008. 'Meta-Regression in Stata.' Stata Journal 8(4): 493-519. doi: 10.1177/1536867X0800800403.

Haubert, Jeannie and Elizabeth Fussell, 2006. 'Explaining Pro-Immigrant Sentiment in the US. Social Class, Cosmopolitanism, and Perceptions of Immigrants.' International Migration Review 40(3): 489-507. doi: 10.1111/j.17477379.2006.00033.x.

Heath, Anthony F. and Lindsay Richards, 2020. 'Contested Boundaries. Consensus and Dissensus in European Attitudes to Immigration.' Journal of Ethnic and Migration Studies 46(3): 489-511. doi: 10.1080/1369183X.2018.1550146. 
Hepler, Justin and Dolores Albarracin, 2013. 'Attitudes without Objects. Evidence for a Dispositional Attitude, Its Measurement, and Its Consequences.' Journal of Personality and Social Psychology 104(6): 1060-76. doi: $10.1037 / \mathrm{a} 0032282$.

Hjerm, Mikael and Kikuko Nagayoshi, 2011. 'The Composition of the Minority Population as a Threat. Can Real Economic and Cultural Threats Explain Xenophobia?' International Sociology 26(6): 815-843. doi: $10.1177 / 0268580910394004$.

Hochschild, Arlie Russel, 2016. Strangers in Their Own Land. Anger and Mourning on the American Right. New York: New Press.

Hout, Michael and Thomas A. DiPrete, 2006. 'What We Have Learned. RC28's Contributions to Knowledge About Social Stratification.' Research in Social Stratification and Mobility 24(1): 1-20. doi: 10.1016/j.rssm.2005.10.001.

Jackson, Michelle and David B. Grusky, 2018. 'A Post-Liberal Theory of Stratification.' British Journal of Sociology 69(4): 1096-1133. doi: 10.1111/14684446.12505 .

Jaime-Castillo, Antonio M. and Ildefonso Marqués-Perales, 2019. 'Social Mobility and Demand for Redistribution in Europe. A Comparative Analysis.' British Journal of Sociology 70(1): 138-165. doi: 10.1111/1468-4446.12363.

Kaiser, Caspar, 2019. 'DRM. Diagonal Reference Model for Stata.' Open Science Framework doi: 10.17605/OSF.IO/KFDP6.

Kaiser, Caspar and Nhat An Trinh, 2019. 'Positional, Mobility, and Reference Effects. How Does Social Class Affect Life Satisfaction in Europe?' Socarxiv doi: 10.31235/osf.io/4adhe.

Kunovich, Robert M., 2004. 'Social Structural Position and Prejudice. An Exploration of Cross-National Differences in Regression Slopes.' Social Science Research 33(1): 20-44. doi: 10.1016/S0049-089X(03)00037-1.

Lipset, Seymour Martin and Reinhard Bendix, 1959. Social Mobility in Industrial Society. Berkeley, CA: University of California Press.

Merton, Robert K., 1968. Social Theory and Social Structure. New York: Free Press.

Mills, Melinda and Patrick Präg, 2016. 'Methodological Advances in CrossNational Research. Multilevel Challenges and Solutions.' European Sociological Review 32(1): 1-2. doi: 10.1093/esr/jcw009. 
Norris, Pippa and Ronald Inglehart, 2019. Cultural Backlash. Trump, Brexit, and Authoritarian Populism. Cambridge: Cambridge University Press. doi: 10.1017/9781108595841.

OECD, 2020. Foreign-Born Population. Paris: Organisation for Economic CoOperation and Development. doi: 10.1787/5a368e1b-en.

Oesch, Daniel, 2013. Occupational Change in Europe. How Technology and Education Transform the Job Structure. Oxford: Oxford University Press. doi: 10.1093/acprof:oso/9780199680962.001.0001.

O'Flynn, Micheal, Lee F. Monaghan, and Martin J. Power, 2014. 'Scapegoating During a Time of Crisis. A Critique of Post-Celtic Tiger Ireland.' Sociology 48(5): 921-937. doi: 10.1177/0038038514539059.

Pardos-Prado, Sergi and Carla Xena, 2019. 'Skill Specificity and Attitudes toward Immigration.' American Journal of Political Science 63(2): 286-304. doi: 10.1111/ajps.12406.

Paskov, Marii, Patrick Präg, and Lindsay Richards, 2020. 'Replication Files to: Does Downward Social Mobility Make People More Hostile towards Immigrants?' Open Science Framework doi: 10.17605/OSF.IO/TPXBH.

Paterson, Lindsay, 2008. 'Political Attitudes, Social Participation, and Social Mobility. A Longitudinal Analysis.' British Journal of Sociology 59(3): 413434. doi: 10.1111/j.1468-4446.2008.00201.x.

Polavieja, Javier G., 2016. 'Labor-Market Competition, Recession, and AntiImmigrant Sentiments in Europe. Occupational and Environmental Drivers of Competitive Threat.' Socio-Economic Review 14(3): 395-417. doi: 10.1093/ser/mww002.

Präg, Patrick, 2019. 'Visualizing Individual Outcomes of Social Mobility Using Heatmaps.' Socius 5: 1-2. doi: 10.1177/2378023119855486.

Präg, Patrick and Lindsay Richards, 2019. 'Intergenerational Social Mobility and Allostatic Load in Great Britain.' Journal of Epidemiology and Community Health 73(2): 100-105. doi: 10.1136/jech-2017-210171.

Quillian, Lincoln, 1995. 'Prejudice as a Response to Perceived Group Threat. Population Composition and Anti-Immigrant and Racial Prejudice in Europe.' American Sociological Review 60(4): 586-611. doi: 10.2307/2096296.

Raftery, Adrian E. and Michael Hout, 1993. 'Maximally Maintained Inequality. Expansion, Reform, and Opportunity in Irish Education, 1921-75.' Sociology of Education 66(1): 41-62. doi: 10.2307/2112784. 
Rose, David and Eric Harrison, 2010. Social Class in Europe. An Introduction to the European Socio-Economic Classification. London: Routledge. doi: $10.4324 / 9780415534239$.

Schneider, Silke L., 2008. 'Anti-Immigrant Attitudes in Europe. Outgroup Size and Perceived Ethnic Threat.' European Sociological Review 24(1): 53-67. doi: $10.1093 / \mathrm{esr} / \mathrm{jcm} 034$.

Semyonov, Moshe, Rebeca Raijman, and Anastasia Gorodzeisky, 2006. 'The Rise of Anti-Foreigner Sentiment in European Societies, 1988-2000.' American Sociological Review 71(3): 426-449. doi: 10.1177/000312240607100304.

Tolsma, Jochem, Nan Dirk De Graaf, and Lincoln Quillian, 2009. 'Does Intergenerational Social Mobility Affect Antagonistic Attitudes Towards Ethnic Minorities?' British Journal of Sociology 60(2): 257-277. doi: 10.1111/j.14684446.2009.01230.x.

Tolsma, Jochem, Marcel Lubbers, and Marcel Coenders, 2007. 'Ethnic Competition and Opposition to Ethnic Intermarriage in the Netherlands. A Multi-Level Approach.' European Sociological Review 24(2): 215-230. doi: $10.1093 / \mathrm{esr} / \mathrm{jcm} 047$.

Van der Waal, Jeroen, Stijn Daenekindt, and Willem de Koster, 2017. 'Statistical Challenges in Modeling the Health Consequences of Social Mobility. The Need for Diagonal Reference Models.' International Journal of Public Health 62(9): 1029-1037. doi: 10.1007/s00038-017-1018-x.

World Bank, 2020. World Development Indicators. Washington, DC: International Bank for Reconstruction and Development.

Wright, Eric Olin, 1997. Class Counts. Comparative Studies in Class Analysis. Cambridge: Cambridge University Press. doi: 10.1017/CBO9780511488917.

Zhao, Yizhang, Yaojun Li, Anthony Heath, and Nick Shryane, 2017. 'Inter- and Intra-Generational Social Mobility Effects on Subjective Wellbeing. Evidence from Mainland China.' Research in Social Stratification and Mobility 48: 54-66. doi: 10.1016/j.rssm.2017.02.002. 


\section{Supplementary materials}

\section{Comparing different measures of migrant stock}

Migrant stock in a country, measured as percentage of the population born abroad, is a control variable in some of the models presented in the main text. We compare two sources of migrant stock in this section to ensure the validity of the measure we use.

The European Social Survey collects information on respondents' country of birth, yet sample sizes are comparatively small, potentially leading to imprecise measures of migrant stock. The OECD (2020) estimates from the International Migration Database are based on more authoritative sources, yet do not cover all countries in our analyses.

Figure A1 plots both data sources against one another, revealing that they are highly correlated $\left(R^{2}=.94\right)$ and thus that the ESS information on migrant stock can be seen as a valid measure.

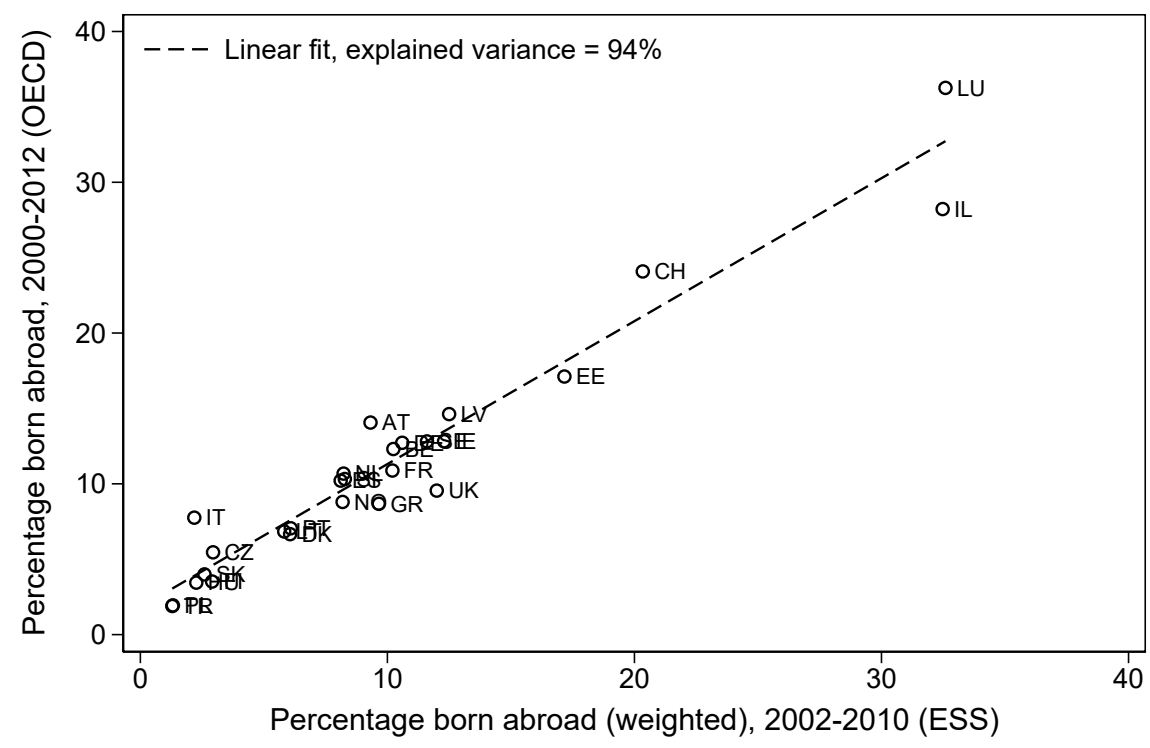

Figure A1: Scatterplot of migrant stock as obtained from the ESS and from the OECD

\section{The social class gradient in anti-immigrant attitudes across countries}

Analyses in the main text reveal a social class gradient in anti-immigrant attitudes. Figure A2 reveals that this social class gradient exists in almost all countries in our sample. 


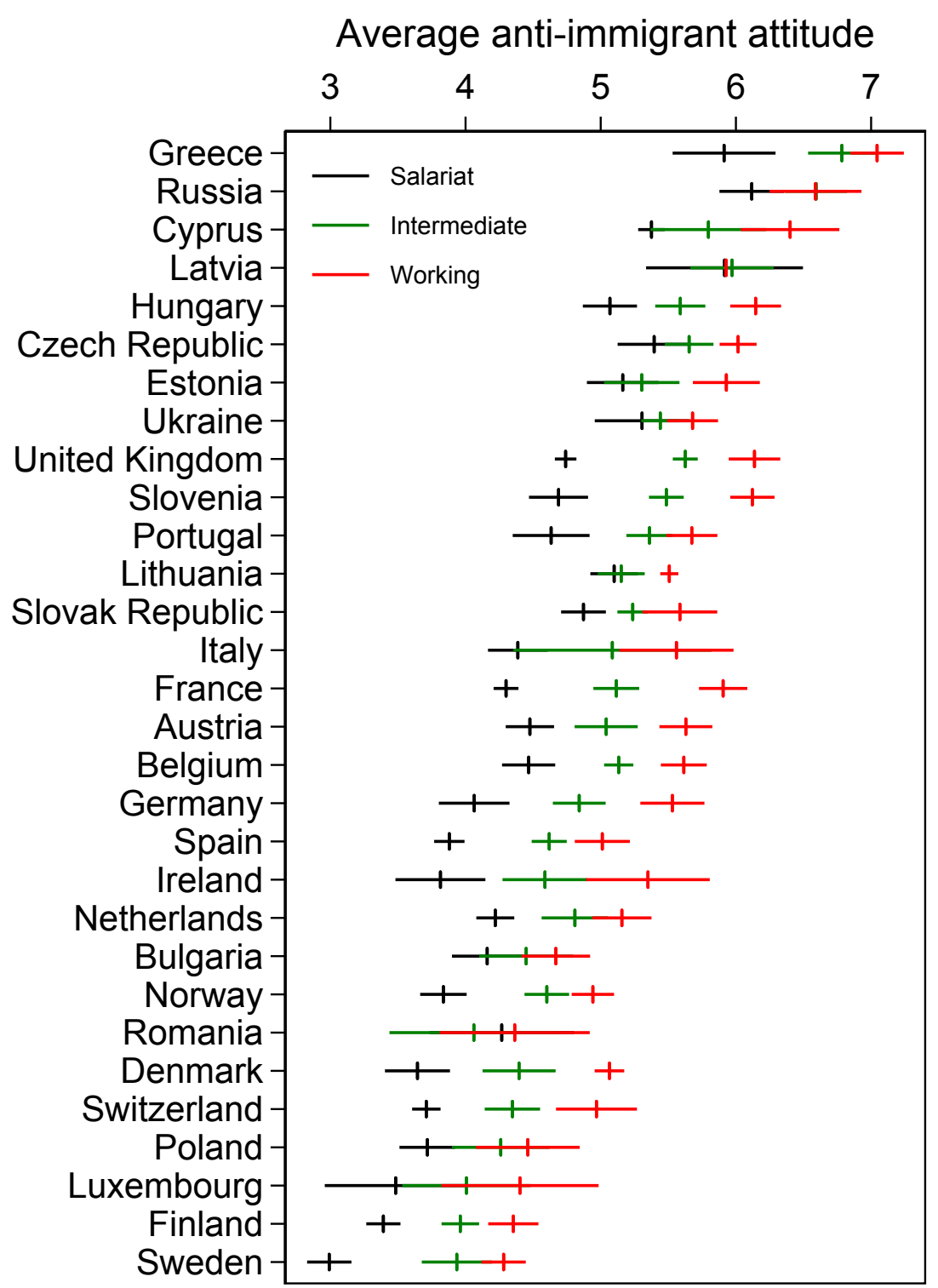

Figure A2: Average anti-immigrant attitudes by social class across Europe with $95 \%$ confidence intervals. 


\section{Accounting for unemployment, more social classes, and mi- grants}

This section presents various robustness checks, namely when we account for unemployment (Table A1), when we use a more detailed class scheme (Table A2), and when we include migrants in the analyses (Table A3). All results remain substantively similar to those presented in the main text.

Table A1: Diagonal reference model of hostility towards migrants, stratified by European region, including unemployment

\begin{tabular}{|c|c|c|c|c|c|c|c|c|}
\hline & $\begin{array}{l}\text { Western Europe } \\
\text { Model 1: Men }\end{array}$ & Model 1: Women & Model 2: Men & Model 2: Women & $\begin{array}{c}\text { Eastern Europe } \\
\text { Model 1: Men }\end{array}$ & Model 1: Women & Model 2: Men & Model 2: Women \\
\hline \multicolumn{9}{|l|}{ Immobiles } \\
\hline Salariat & $\begin{array}{c}-1.08^{* * *} \\
(0.05)\end{array}$ & $\begin{array}{c}-1.01^{* * *} \\
(0.05)\end{array}$ & $\begin{array}{c}-1.09^{* * *} \\
(0.06)\end{array}$ & $\begin{array}{c}-1.02^{* * *} \\
(0.05)\end{array}$ & $\begin{array}{c}-0.67^{* * *} \\
(0.10)\end{array}$ & $\begin{array}{c}-0.54^{* * *} \\
(0.09)\end{array}$ & $\begin{array}{c}-0.67^{* * *} \\
(0.11)\end{array}$ & $\begin{array}{c}-0.56^{* * *} \\
(0.10)\end{array}$ \\
\hline Intermediate & $\begin{array}{l}-0.03 \\
(0.04)\end{array}$ & $\begin{array}{c}-0.06 \\
(0.05)\end{array}$ & $\begin{array}{c}-0.03 \\
(0.05)\end{array}$ & $\begin{array}{l}-0.07 \\
(0.05)\end{array}$ & $\begin{array}{c}-0.13 \\
(0.07)\end{array}$ & $\begin{array}{c}-0.07 \\
(0.06)\end{array}$ & $\begin{array}{c}-0.13 \\
(0.12)\end{array}$ & $\begin{array}{c}-0.06 \\
(0.08)\end{array}$ \\
\hline Working & $\begin{array}{c}0.50^{* * * *} \\
(0.04)\end{array}$ & $\begin{array}{c}0.59^{* * * *} \\
(0.05)\end{array}$ & $\begin{array}{c}0.50^{* * * *} \\
(0.04)\end{array}$ & $\begin{array}{c}0.59^{* * * *} \\
(0.05)\end{array}$ & $\begin{array}{c}0.24^{* * *} \\
(0.06)\end{array}$ & $\begin{array}{c}0.21^{* * *} \\
(0.05)\end{array}$ & $\begin{array}{l}0.25^{*} \\
(0.10)\end{array}$ & $\begin{array}{c}0.19^{* * *} \\
(0.06)\end{array}$ \\
\hline Unemployed & $\begin{array}{c}0.61^{* * *} \\
(0.09)\end{array}$ & $\begin{array}{c}0.48^{* * *} \\
(0.08)\end{array}$ & $\begin{array}{c}0.63^{* * *} \\
(0.10)\end{array}$ & $\begin{array}{c}0.49^{* * *} \\
(0.08)\end{array}$ & $\begin{array}{c}0.56^{* * *} \\
(0.11)\end{array}$ & $\begin{array}{c}0.40^{* * *} \\
(0.09)\end{array}$ & $\begin{array}{c}0.55^{* * *} \\
(0.13)\end{array}$ & $\begin{array}{c}0.42^{* * *} \\
(0.11)\end{array}$ \\
\hline \multicolumn{9}{|l|}{ Origin weight } \\
\hline Origin weight & $\begin{array}{c}0.30 \\
(0.02)\end{array}$ & $\begin{array}{c}0.36 \\
(0.02)\end{array}$ & $\begin{array}{c}0.34 \\
(0.05)\end{array}$ & $\begin{array}{c}0.35 \\
(0.03)\end{array}$ & $\begin{array}{c}0.31 \\
(0.06)\end{array}$ & $\begin{array}{c}0.38 \\
(0.03)\end{array}$ & $\begin{array}{c}0.35 \\
(0.24)\end{array}$ & $\begin{array}{c}0.53 \\
(0.14)\end{array}$ \\
\hline \multicolumn{9}{|l|}{ Covariates } \\
\hline Age (centered) & $\begin{array}{c}0.00 \\
(0.00)\end{array}$ & $\begin{array}{c}0.00^{* *} \\
(0.00)\end{array}$ & $\begin{array}{c}0.00 \\
(0.00)\end{array}$ & $\begin{array}{l}0.00^{* *} \\
(0.00)\end{array}$ & $\begin{array}{c}0.01^{* * *} \\
(0.00)\end{array}$ & $\begin{array}{c}0.01^{* * *} \\
(0.00)\end{array}$ & $\begin{array}{c}0.01^{* * *} \\
(0.00)\end{array}$ & $\begin{array}{c}0.01^{* * *} \\
(0.00)\end{array}$ \\
\hline Downwardly mobile & & & $\begin{array}{c}0.06 \\
(0.09)\end{array}$ & $\begin{array}{l}-0.02 \\
(0.06)\end{array}$ & & & $\begin{array}{c}0.06 \\
(0.29)\end{array}$ & $\begin{array}{c}0.18 \\
(0.14)\end{array}$ \\
\hline Stable & & & $\begin{array}{c}0.08 \\
(0.06)\end{array}$ & $\begin{array}{c}0.02 \\
(0.05)\end{array}$ & & & $\begin{array}{c}-0.00 \\
(0.21)\end{array}$ & $\begin{array}{c}0.11 \\
(0.09)\end{array}$ \\
\hline Constant & $\begin{array}{c}5.18^{* * *} \\
(0.05)\end{array}$ & $\begin{array}{c}5.10^{* * *} \\
(0.04)\end{array}$ & $\begin{array}{c}5.13^{* * *} \\
(0.08)\end{array}$ & $\begin{array}{c}5.10^{* * *} \\
(0.07)\end{array}$ & $\begin{array}{c}4.51^{* * *} \\
(0.26)\end{array}$ & $\begin{array}{c}4.59^{* * *} \\
(0.18)\end{array}$ & $\begin{array}{c}4.49^{* * * *} \\
(0.21)\end{array}$ & $\begin{array}{c}4.49^{* * *} \\
(0.14)\end{array}$ \\
\hline Country dummies included & Yes & Yes & Yes & Yes & Yes & Yes & Yes & Yes \\
\hline Survey round dummies included & Yes & Yes & Yes & Yes & Yes & Yes & Yes & Yes \\
\hline Observations & 33,698 & 36,143 & 33,698 & 36,143 & 15,042 & 17,903 & 15,042 & 17,903 \\
\hline AIC & 139520.0 & 146633.7 & 139517.5 & 146635.9 & 64577.8 & 76042.3 & 64578.5 & 76040.7 \\
\hline BIC & 139604.2 & 146718.7 & 139618.6 & 146737.8 & 64654.0 & 76120.2 & 64662.3 & 76126.4 \\
\hline
\end{tabular}

Notes: Cluster-robust SE's in parer
${ }^{*} \mathrm{p}<.05, * * \mathrm{p}<.01,{ }^{* * * *} \mathrm{p}<.001$.

Destination parameters (which equal $-1 *$ origin parameters) and destination weight (which equals 1 - origin weight) not displayed.

\section{Intercorrelations of country-level variables}

Table A4 presents Pearson correlations between the country-level variables. 
Table A2: Diagonal reference model of hostility towards migrants, stratified by gender and European region, five-class scheme

\begin{tabular}{|c|c|c|c|c|c|c|c|c|}
\hline & $\begin{array}{l}\text { Western Europe } \\
\text { Model 1: Men }\end{array}$ & Model 1: Women & Model 2: Men & Model 2: Women & $\begin{array}{l}\text { Eastern Europe } \\
\text { Model 1: Men }\end{array}$ & Model 1: Women & Model 2: Men & Model 2: Women \\
\hline \multicolumn{9}{|l|}{ Immobiles } \\
\hline High salariat & $\begin{array}{c}-1.02^{* * *} \\
(0.05)\end{array}$ & $\begin{array}{c}-1.02^{* * *} \\
(0.05)\end{array}$ & $\begin{array}{c}-1.03^{* * *} \\
(0.06)\end{array}$ & $\begin{array}{c}-0.98^{* * *} \\
(0.05)\end{array}$ & $\begin{array}{c}-0.62^{* * *} \\
(0.10)\end{array}$ & $\begin{array}{c}-0.50^{* * *} \\
(0.10)\end{array}$ & $\begin{array}{c}-0.67^{* * *} \\
(0.11)\end{array}$ & $\begin{array}{c}-0.51^{* * *} \\
(0.09)\end{array}$ \\
\hline Low salariat & $\begin{array}{c}-0.71^{* * *} \\
(0.04)\end{array}$ & $\begin{array}{c}-0.71^{* * *} \\
(0.04)\end{array}$ & $\begin{array}{c}-0.70^{* * *} \\
(0.04)\end{array}$ & $\begin{array}{c}-0.71^{* * *} \\
(0.04)\end{array}$ & $\begin{array}{c}-0.36^{* * *} \\
(0.06)\end{array}$ & $\begin{array}{c}-0.32^{* * *} \\
(0.05)\end{array}$ & $\begin{array}{c}-0.36^{* * *} \\
(0.05)\end{array}$ & $\begin{array}{c}-0.31^{* * *} \\
(0.06)\end{array}$ \\
\hline Intermediate & $\begin{array}{c}0.21^{* * *} \\
(0.03)\end{array}$ & $\begin{array}{l}0.12^{* *} \\
(0.04)\end{array}$ & $\begin{array}{c}0.20^{* * *} \\
(0.04)\end{array}$ & $\begin{array}{l}0.11^{*} \\
(0.04)\end{array}$ & $\begin{array}{c}0.08 \\
(0.07)\end{array}$ & $\begin{array}{c}0.07 \\
(0.06)\end{array}$ & $\begin{array}{c}0.10 \\
(0.08)\end{array}$ & $\begin{array}{c}0.08 \\
(0.05)\end{array}$ \\
\hline Lower service & $\begin{array}{c}\left(0.64^{* * *}\right. \\
(0.05)\end{array}$ & $\begin{array}{c}0.64^{* * *} \\
(0.06)\end{array}$ & $\begin{array}{c}0.65^{* * *} \\
(0.05)\end{array}$ & $\begin{array}{c}0.63^{* * *} \\
(0.06)\end{array}$ & $\begin{array}{c}0.37^{* * *} \\
(0.07)\end{array}$ & $\begin{array}{c}0.27^{* * *} \\
(0.04)\end{array}$ & $\begin{array}{c}0.39^{* * *} \\
(0.07)\end{array}$ & $\begin{array}{c}0.27^{* * *} \\
(0.05)\end{array}$ \\
\hline Routine & $\begin{array}{c}0.88^{* * *} \\
(0.05)\end{array}$ & $\begin{array}{c}0.97^{* * *} \\
(0.06)\end{array}$ & $\begin{array}{c}0.89^{* * *} \\
(0.04)\end{array}$ & $\begin{array}{c}0.96^{* * *} \\
(0.05)\end{array}$ & $\begin{array}{c}0.52^{* * *} \\
(0.06)\end{array}$ & $\begin{array}{c}0.47^{* * *} \\
(0.10)\end{array}$ & $\begin{array}{c}0.54^{* * *} \\
(0.06)\end{array}$ & $\begin{array}{c}0.47^{* * *} \\
(0.10)\end{array}$ \\
\hline \multicolumn{9}{|l|}{ Origin weight } \\
\hline Origin weight & $\begin{array}{c}0.30 \\
(0.02)\end{array}$ & $\begin{array}{c}0.34 \\
(0.02)\end{array}$ & $\begin{array}{c}0.27 \\
(0.03)\end{array}$ & $\begin{array}{c}0.30 \\
(0.03)\end{array}$ & $\begin{array}{c}0.29 \\
(0.05)\end{array}$ & $\begin{array}{c}0.33 \\
(0.03)\end{array}$ & $\begin{array}{c}0.37 \\
(0.07)\end{array}$ & $\begin{array}{c}0.32 \\
(0.09)\end{array}$ \\
\hline \multicolumn{9}{|l|}{ Covariates } \\
\hline Age (centered) & $\begin{array}{c}0.00 \\
(0.00)\end{array}$ & $\begin{array}{l}0.00^{* *} \\
(0.00)\end{array}$ & & $\begin{array}{l}0.00^{* *} \\
(0.00)\end{array}$ & $\begin{array}{c}0.01^{* * *} \\
(0.00)\end{array}$ & $\begin{array}{c}0.01^{* * *} \\
(0.00)\end{array}$ & $\begin{array}{c}0.01^{* * *} \\
(0.00)\end{array}$ & $\begin{array}{c}0.01^{* * *} \\
(0.00)\end{array}$ \\
\hline Downwardly mobile & & & $\begin{array}{l}-0.07 \\
(0.06)\end{array}$ & $\begin{array}{c}-0.08 \\
(0.06)\end{array}$ & & & $\begin{array}{c}0.09 \\
(0.08)\end{array}$ & $\begin{array}{c}-0.01 \\
(0.07)\end{array}$ \\
\hline Stable & & & $\begin{array}{c}0.03 \\
(0.08)\end{array}$ & $\begin{array}{l}-0.12 \\
(0.08)\end{array}$ & & & $\begin{array}{c}0.11 \\
(0.14)\end{array}$ & $\begin{array}{c}0.03 \\
(0.17)\end{array}$ \\
\hline Constant & $\begin{array}{c}4.97^{* * *} \\
(0.04)\end{array}$ & $\begin{array}{c}4.95^{* * *} \\
(0.04)\end{array}$ & $\begin{array}{c}4.99^{* * *} \\
(0.05)\end{array}$ & $\begin{array}{c}4.98^{* * *} \\
(0.04)\end{array}$ & $\begin{array}{c}4.38^{* * *} \\
(0.27)\end{array}$ & $\begin{array}{c}4.46^{* * *} \\
(0.19)\end{array}$ & $\begin{array}{c}4.34^{* * *} \\
(0.28)\end{array}$ & $\begin{array}{l}4.47^{* * *} \\
(0.19)\end{array}$ \\
\hline Country dummies included & Yes & Yes & Yes & Yes & Yes & Yes & Yes & Yes \\
\hline Survey round dummies included & Yes & Yes & Yes & Yes & Yes & Yes & Yes & Yes \\
\hline Observations & 32,007 & 34,064 & 32,007 & 34,064 & 14,225 & 17,036 & 14,225 & 17,036 \\
\hline AIC & 132211.4 & 137792.8 & 132212.5 & 137791.2 & 61006.7 & 72252.1 & 61004.8 & 72251.9 \\
\hline BIC & 132303.5 & 137885.6 & 132313.0 & 137900.9 & 61089.9 & 72337.2 & 61087.9 & 72337.1 \\
\hline
\end{tabular}

Table A3: Diagonal reference model of hostility towards migrants, stratified by gender and European region, including migrants

\begin{tabular}{|c|c|c|c|c|c|c|c|c|}
\hline & $\begin{array}{l}\text { Western Europe } \\
\text { Model 1: Men }\end{array}$ & Model 1: Women & Model 2: Men & Model 2: Women & $\begin{array}{c}\text { Eastern Europe } \\
\text { Model 1: Men }\end{array}$ & Model 1: Women & Model 2: Men & Model 2: Women \\
\hline \multicolumn{9}{|l|}{ Immobiles } \\
\hline Salariat & $\begin{array}{c}-0.83^{* * *} \\
(0.04)\end{array}$ & $\begin{array}{c}-0.81^{* * *} \\
(0.03)\end{array}$ & $\begin{array}{c}-0.83^{* * *} \\
(0.04)\end{array}$ & $\begin{array}{c}-0.81^{* * *} \\
(0.03)\end{array}$ & $\begin{array}{c}-0.46^{* * *} \\
(0.07)\end{array}$ & $\begin{array}{c}-0.39^{* * *} \\
(0.07)\end{array}$ & $\begin{array}{c}-0.47^{* * *} \\
(0.08)\end{array}$ & $\begin{array}{c}-0.40^{* * *} \\
(0.08)\end{array}$ \\
\hline Intermediate & $\begin{array}{c}0.17^{* * *} \\
(0.03)\end{array}$ & $\begin{array}{l}0.09^{* *} \\
(0.03)\end{array}$ & $\begin{array}{c}0.17^{* * *} \\
(0.03)\end{array}$ & $\begin{array}{l}0.09^{* *} \\
(0.03)\end{array}$ & $\begin{array}{c}0.05 \\
(0.06)\end{array}$ & $\begin{array}{c}0.04 \\
(0.05)\end{array}$ & $\begin{array}{c}0.06 \\
(0.10)\end{array}$ & $\begin{array}{c}0.06 \\
(0.07)\end{array}$ \\
\hline Working & $\begin{array}{c}0.66^{* * *} \\
(0.04)\end{array}$ & $\begin{array}{c}0.71^{* * *} \\
(0.05)\end{array}$ & $\begin{array}{c}0.66^{* * *} \\
(0.04)\end{array}$ & $\begin{array}{c}0.72^{* * *} \\
(0.05)\end{array}$ & $\begin{array}{c}0.41^{* * *} \\
(0.06)\end{array}$ & $\begin{array}{c}0.35^{* * *} \\
(0.06)\end{array}$ & $\begin{array}{c}0.41^{* * *} \\
(0.07)\end{array}$ & $\begin{array}{c}0.34^{* * *} \\
(0.06)\end{array}$ \\
\hline \multicolumn{9}{|l|}{ Origin weight } \\
\hline Origin weight & $\begin{array}{c}0.29 \\
(0.01)\end{array}$ & $\begin{array}{c}0.36 \\
(0.02)\end{array}$ & $\begin{array}{c}0.27 \\
(0.04) \\
\end{array}$ & $\begin{array}{c}0.31 \\
(0.04)\end{array}$ & $\begin{array}{c}0.30 \\
(0.06)\end{array}$ & $\begin{array}{c}0.37 \\
(0.04)\end{array}$ & $\begin{array}{c}0.37 \\
(0.20)\end{array}$ & $\begin{array}{c}0.55 \\
(0.15) \\
\end{array}$ \\
\hline \multicolumn{9}{|l|}{ Covariates } \\
\hline Age (centered) & $\begin{array}{l}0.00^{*} \\
(0.00)\end{array}$ & $\begin{array}{c}0.01^{* * *} \\
(0.00)\end{array}$ & $\begin{array}{l}0.00^{*} \\
(0.00)\end{array}$ & $\begin{array}{c}0.01^{* * *} \\
(0.00)\end{array}$ & $\begin{array}{c}0.01^{* * *} \\
(0.00)\end{array}$ & $\begin{array}{c}0.01^{* * *} \\
(0.00)\end{array}$ & $\begin{array}{c}0.01^{* * *} \\
(0.00)\end{array}$ & $\begin{array}{c}0.01^{* * *} \\
(0.00)\end{array}$ \\
\hline Yes & $\begin{array}{c}-0.53^{* * *} \\
(0.07)\end{array}$ & $\begin{array}{c}-0.42^{* * *} \\
(0.07)\end{array}$ & $\begin{array}{c}-0.53^{* * *} \\
(0.07)\end{array}$ & $\begin{array}{c}-0.42^{* * *} \\
(0.07)\end{array}$ & $\begin{array}{c}-0.52^{* * *} \\
(0.10)\end{array}$ & $\begin{array}{c}-0.55^{* * * *} \\
(0.10)\end{array}$ & $\begin{array}{c}-0.52^{* * *} \\
(0.10)\end{array}$ & $\begin{array}{c}-0.55^{* * *} \\
(0.10)\end{array}$ \\
\hline Yes & $\begin{array}{c}-0.70^{* * *} \\
(0.09)\end{array}$ & $\begin{array}{c}-0.67^{* * *} \\
(0.10)\end{array}$ & $\begin{array}{c}-0.70^{* * *} \\
(0.09)\end{array}$ & $\begin{array}{c}-0.67^{* * *} \\
(0.10)\end{array}$ & $\begin{array}{c}-0.55^{* * *} \\
(0.13)\end{array}$ & $\begin{array}{l}-0.19^{*} \\
(0.08)\end{array}$ & $\begin{array}{c}-0.55^{* * *} \\
(0.13)\end{array}$ & $\begin{array}{l}-0.19^{*} \\
(0.08)\end{array}$ \\
\hline \multicolumn{9}{|l|}{ Mobility parameters (ref. upward) } \\
\hline Downwardly mobile & & & $\begin{array}{l}-0.05 \\
(0.10)\end{array}$ & $\begin{array}{l}-0.11 \\
(0.10)\end{array}$ & & & $\begin{array}{c}0.09 \\
(0.22)\end{array}$ & $\begin{array}{c}0.21 \\
(0.15)\end{array}$ \\
\hline Stable & & & $\begin{array}{c}0.02 \\
(0.06)\end{array}$ & $\begin{array}{l}-0.05 \\
(0.06)\end{array}$ & & & $\begin{array}{c}0.04 \\
(0.15)\end{array}$ & $\begin{array}{c}0.13 \\
(0.08)\end{array}$ \\
\hline Constant & $\begin{array}{l}5.00^{* * *} \\
(0.04)\end{array}$ & $\begin{array}{c}4.98^{* * *} \\
(0.05)\end{array}$ & $\begin{array}{c}5.00^{* * * *} \\
(0.07)\end{array}$ & $\begin{array}{c}5.03^{* * *} \\
(0.07)\end{array}$ & $\begin{array}{c}4.50^{* * *} \\
(0.27)\end{array}$ & $\begin{array}{c}4.60^{* * *} \\
(0.20)\end{array}$ & $\begin{array}{c}4.45^{* * *} \\
(0.25)\end{array}$ & $\begin{array}{c}4.48^{* * *} \\
(0.16)\end{array}$ \\
\hline Country dummies included & Yes & Yes & Yes & Yes & Yes & Yes & Yes & Yes \\
\hline Survey round dummies included & Yes & Yes & Yes & Yes & Yes & Yes & Yes & Yes \\
\hline Observations & 36,203 & 38,537 & 36,203 & 38,537 & 15,139 & 18,297 & 15,139 & 18,297 \\
\hline AIC & 149787.3 & 156278.8 & 149784.9 & 156280.4 & 65175.3 & 77821.2 & 65174.8 & 77817.4 \\
\hline BIC & 149880.8 & 156373.0 & 149895.3 & 156391.7 & 65259.1 & 77907.1 & 65258.7 & 77903.3 \\
\hline
\end{tabular}

${ }^{*} \mathrm{p}<.05,{ }^{* *} \mathrm{p}<.01,{ }^{* * * *} \mathrm{p}<.001$

Destination parameters (which equal $-1 *$ origin parameters) and destination weight (which equals 1 - origin weight) not displayed. 
Table A4: Correlation matrix of macro-level variables

\begin{tabular}{|c|c|c|c|c|c|c|c|c|}
\hline & Downward & Upward & Downward/upward & Unidiff & Global log odds & GDP per capita & GDP per capita, logged & $\%$ foreign born \\
\hline Downward & 1 & & & & & & & \\
\hline Upward & $-0.810^{* * *}$ & 1 & & & & & & \\
\hline Upward/downward & $-0.921^{* * *}$ & $0.932^{* * *}$ & 1 & & & & & \\
\hline Unidiff & $-0.665^{* * *}$ & 0.322 & $0.503^{* *}$ & 1 & & & & \\
\hline Global log odds & -0.167 & -0.0311 & 0.0926 & $0.705^{* * *}$ & 1 & & & \\
\hline GDP per capita & $-0.553^{* *}$ & $0.612^{* * * *}$ & $0.656^{* * *}$ & 0.195 & -0.186 & 1 & & \\
\hline GDP per capita, logged & $-0.545^{* *}$ & $0.577^{\text {*** }}$ & $0.618^{* * *}$ & 0.199 & -0.226 & $0.938^{* * *}$ & 1 & \\
\hline$\%$ foreign born & -0.232 & 0.356 & $0.430^{*}$ & -0.0809 & -0.152 & $0.650^{* * *}$ & $0.510^{* *}$ & 1 \\
\hline
\end{tabular}

